\title{
COMMENT
}

\section{THE GREATION OF A COMMON LAW RULE: THE FELLOW SERVANT RULE, 1837-1860}

\section{INTRODUCTION}

Searching for a comprehensive explanation of the nature of legal change is like searching for an honest man: the quest is often more illuminating than the conclusion. The quest has recently been undertaken by a new generation of legal historians who have focused upon the development of modern private law doctrines in nineteenth-century America. ${ }^{1}$ One such doctrine, the Fellow Servant rule, presents a stark and self-contained example of common law development. This Comment examines the development of the rule to see if such an examination can clarify the interplay between competing explanations of nineteenth-century legal change.

The Fellow Servant rule was a rule of tort law created in the midnineteenth century. It carved out an exception to the well-established rule of respondeat superior, and relieved employers of liability for injuries negligently inflicted by any employee upon a "fellow servant." The rule did not exist until 1837, when it was first pronounced in England by Lord Abinger in Priestley $v$. Fowler. ${ }^{2}$ In 1842 Chief Justice Lemuel Shaw of Massachusetts gave the rule its American reception and rationale in the leading case of Farwell $v$. Boston $\mathcal{E}$ Worcester Rail Road. $^{3}$ By 1880 the rule, in one form or another, was so firmly entrenched in nearly every American jurisdiction that late nineteenth-century treatise writers warned legislatures and courts against tampering with "a rule of the common law, based upon the wisdom and precedents of the ages."

I See, e.g., M. Horwitz, The Transformation of American Law, 17801860 (1977); G. Whire, TORT LAW IN America (1980); Feinman, The Development of the Employment at Will Rule, 20 AM. J. LeGal Hist. 118 (1976); Schwartz, Tort Law and the Economy in Nineteenth-Century America: A Reinterpretation, 90 YALE L.J. 1717 (1981).

2150 Eng. Rep. 1030, 1032-33 (1837).

s 45 Mass. (4 Met.) 49 (1842).

- 1 E. White, Law of Personal Injuries on Railroads 417 (1909); see also M. BigelOW, LAW OF TORTS 707 (1875). By 1854, barely 12 years after Farwell, the railroad attorney in the first Illinois Fellow Servant case blandly asserted that "[t]he general rule, that the master is not liable for injuries sustained by one servant through the wrongful act or negligence of another, is established by the overwhelming weight of 
Commentators have used the rule to illustrate conflicting theories concerning the nature of legal development. These writers fall into two broad categories: those who view legal change largely as a function of the legal community's response to social and economic changes in society, and those who see it primarily as a response to forces within the legal community.

The clearest, and perhaps simplest, explanation is that of the economic and social determinists. They view legal development, in general, as a product of the legal system's close adaption to changes in society. To such theorists the Fellow Servant rule is an example of the general development of tort law in the direction of protecting nascent industry in an industrializing society. ${ }^{5}$

The major new version of this interpretation is that of Morton J. Horwitz. ${ }^{6}$ While previous economic and social determinists depicted legal change largely as a passive response to changes in society at large, Horwitz's exhaustive study of the changes in American private law in the nineteenth-century describes a conscious effort by the legal establishment "to promote economic growth primarily through the legal ... system." To Horwitz, nineteenth-century common law judges were deliberate and conscious sources of legal change, purposefully shaping private law to accommodate the needs of their social and economic partners in the entrepreneurial classes. ${ }^{8}$ To these "instrumentalist" judges, the private law was malleable. Their role was to mold it by discarding or reshaping ancient common law doctrines and English precedents and thereby to render the nineteenth-century legal system consonant with the social and economic needs of an industrializing

authority." Honner v. Illinois Cent. R.R., 15 Ill. 550 (1854) (citations omitted).

- A premier advocate of the view that nineteenth-century tort law is an example of the passive response of the legal system to changes in society at large is Laurence Friedman. See, e.g., L. Friedman, A History of American Law 262 (1973); see also J. Fleming, The Law of Torts 4-6 (1967); Friedman \& Ladinsky, Social Change and the Law of Industrial Accidents, 67 Colum. L. Rev. 50 (1967). For an approving view of common law adaptability, see McClain, Legal Change and Class Interests: A Review Essay on Morton Horwitz's 'The Transformation of American Law,' 68 CALIF. L. REv. 382, 396-97 (1980) ("[t]hese changes appear to reflect the legal order's responsiveness to changed social conditions and its ability to evolve in the direction of greater flexibility, greater materiality, and, indeed, greater plain common sense").

$\checkmark$ M. HoRwiTz, supra note 1.

7 Id. at $\mathrm{xv}$.

8 See id. at 30, 253-54. As McClain notes, "[t]he Horwitz thesis is therefore one that posits orchestrated and purposive legal change." McClain, supra note 5, at 39192. The theme of purposive legal change predated Horwitz. See, e.g., Rabin, Some Thoughts on Tort Law from a Sociopolitical Perspective, 1969 WIS. L. REv. 51, 60-62 (discussing formulation of legal doctrines affecting liability for injuries from industrial accidents and defective products). 


\section{America. ${ }^{9}$}

Central to Horwitz's thesis is a stringent periodization; Horwitz separates the early nineteenth-century period of dynamic legal change from the static eighteenth-century world which preceded it and from the late nineteenth-century era of legal formalism which followed it when the triumphant entrepreneurial classes sought to consolidate the gains they had won earlier. ${ }^{10}$ For Horwitz, the development of the Fellow Servant rule exemplified the process by which instrumentalist judges like Lemuel Shaw molded private law in the early nineteenth century to accommodate the needs of the entrepreneurial classes. ${ }^{11}$

A far different perspective on nineteenth-century legal change, and on the Fellow Servant rule, is presented by those scholars who view legal development not as a reaction to social and economic change, but rather primarily as a response to intellectual forces within the legal community itself. ${ }^{12}$ While social change may have provided the occasion

${ }^{9} \mathrm{M}$. HoRwitz, supra note 1, at 1-30; see also Rabin, supra note 8, at 56 ("The judicial concern was to allocate resources optimally in light of perceptions of the 'public' dimension of the problem; in other words, in view of the societal interest in encouraging industrial growth."). This activist, or instrumental, model of judicial activity, stripped of its nineteenth-century economic substance, has recently been cited approvingly as the appropriate model for present-day common law judges. See Ursin, Judicial Creativity and Tort Law, 49 GEo. WASH. L. REv. 229, 231, 251-59, 304-08 (1981). On the use of English precedent, see infra text accompanying notes 52-56. It is interesting to note that English commentators on the development of the Fellow Servant rule (the doctrine of common employment) view it not as a farsighted, if harsh, accommodation of the legal system to industrial interests, but rather as a product of backwardlooking nineteenth-century judges seeking to recreate a simpler eighteenth-century world of master-servant relationships. See Smith, Judges and the Lagging Law of Compensation for Personal Injuries in the Nineteenth Century, 2 J. LEGAL HIST. 258 (1981).

${ }_{10}$ M. HoRwITz, supra note 1, at 1-30, 253-66. As Horwitz notes,

[t]he rise of legal formalism can be fully correlated with the attainment of these substantive legal changes. If a flexible, instrumental conception of law was necessary to promote the transformation of the post-revolutionary American legal system, it was no longer needed once the major beneficiaries of that transformation had obtained the bulk of their objectives. Indeed, once successful, those groups could only benefit if both the recent origins and the foundations in policy and group self-interest of all newly established legal doctrines could be disguised. There were, in short, major advantages in creating an intellectual system which gave common law rules the appearance of being self-contained, apolitical, and inexorable

...

Id. at 254 .

For a critical view of Horwitz's periodization, see Simpson, The Horwitz Thesis and the History of Contracts, 46 U. CHI. L. REV. 533 (1979).

11 See. M. HoRwIT, supra note 1, at 201-04, 208-10, 253-54.

12 See, e.g., G. WHITE, supra note 1, at 16 (agreeing with the "conventional identification of the rise of Torts with the advent of industrialism," but characterizing its development as "an intellectual response to the increased number of accidents involving persons who had no preexisting relationship with one another"). 
for legal change, they believe, it cannot provide a sufficient explanation for the direction such legal development took. ${ }^{13}$ Thus, for example, one modern scholar, G. Edward White, has attributed the development of nineteenth-century tort law largely to "changes in jurisprudential thought."14 In such a scheme, the intellectual force of the arguments of premier judges like Lemuel Shaw assumes major significance. ${ }^{15}$

When considering the role of intellectual factors in impelling legal change, it is important to remember that the intellectual process need not result in a set of legal rules that are either consistent or coherent. As Alan Watson notes, legal change can result from lawyers talking to judges talking to theorists, and the result can be at odds with any particular society's social or economic needs. ${ }^{16}$

13 These scholars draw their inspiration from Roscoe Pound's conception that the "[t]enacity of a taught legal tradition is much more significant in our legal history than the economic conditions of time and place." R. POUND, THE Formative ERA OF American Law 82 (1938) [hereinafter cited as R. Pound, Formative ERa]. For Pound, the Fellow Servant rule was a rational judicial response to the then-current trend of judicial decisions toward limiting strict liability, rather than "something adopted wilfully in 1837 by a tribunal consciously expressing in legal doctrine the self interest of a dominant social or economic class." Pound, The Economic Interpretation and the Law of Torts, 53 HARv. L. REv. 365, 379 (1940); see also id. at 382.

$14 \mathrm{G}$. WHITE, supra note 1 , at 3 . White attributes the development of modern tort law to the efforts of nineteenth-century scholars and judges, marching under the banner of "legal science," to order and rationalize the ancient, haphazard writ system. Id. at 12,14 .

1s This view is shared by L. Levy, The LAw of the Commonwealth and Chief Justice Shaw 167 (1957). Levy believes that the sheer force of Shaw's creativity and the inescapable intellectual rigor of his argument caused American courts to follow Farwell. For a similar view of Shaw's influence, see Ursin, supra note 9, at 259-63.

${ }_{16}$ See A. Watson, Society and Legal Ghange 8 (1977). But see Abel, Law as Lag: Inertia as a Social Theory of Law (Book Review), 80 Mrch. L. Rev. 785 (1982) (reviewing A. WATSON, Society and Legal Change (1977)); Dawson, Book Review, 49 U. ChI. L. Rev. 595 (1982) (reviewing A. Watson, The Making of Crvil LAw (1981)); Friedman, Book Review, 6 BRIT. J.L. \& Soc. 127 (1979) (reviewing A. Watson, Society and Legal Change (1977)). Such criticism is beyond the scope of this Comment. As a counter to White's view of intellectual coherence, however, Watson presents an interesting counterpoint by which to test the development of a rule which was, by the end of the nineteenth century, devoid of coherence.

Also beyond the scope of this Comment is an analysis of the Fellow Servant rule in the light of the well-known economic efficiency theories development by Richard Posner and his followers. See, e.g., Posner, A Theory of Negligence, 1 J. Legal STud. 29 (1972); Posner, Change in the Common Law: Legal and Economic Perspectives, $9 \mathrm{~J}$. LEGAl STud. 189 (1980) [hereinafter cited as Posner, Change in the Common Law]. Posner views nineteenth-century judges as following the "invisible hand" of economic efficiency whether consciously or not. They thereby created a tort law which maximized the efficient allocation of resources in an industrializing society. Posner's view focuses heavily on a retrospective analysis of rules like the Fellow Servant rule. See generally Posner, Change in the Common Law, supra. This Comment, however, focuses not on the economic effects of the rule, but rather upon the process by which it was created. Posner's analysis is not, therefore, particularly relevant to the questions posed here. 
This Comment examines the sufficiency of these views to account for the development of the Fellow Servant rule. It traces the migration of the rule through various jurisdictions through a study of cases of first impression. Such cases are excellent vehicles for examining the migration of any doctrine, for in adopting or rejecting any particular rule, judges feel a particular burden of explanation. ${ }^{17}$

Part I of the Comment discusses the English and American cases that established the Fellow Servant rule. This section suggests that these cases were followed by subsequent courts at least in part because of intellectual forces within the legal community. The Comment argues that among the intellectual forces shaping the rule was the continuing eighteenth-century myth that the role of judges was to "discover" rather than to make the rules of the common law. Once correctly discovered, these judges believed, such rules must be strictly adhered to by subsequent courts. ${ }^{18}$

Part II examines those jurisdictions that resisted the Fellow Servant rule by creating exceptions to it. It suggests that common law judges chose to resist the rule by creating exceptions to it rather than by rejecting it outright, and that their choice was shaped primarily by contemporary legal norms.

The Comment concludes that no explanation of the development of the Fellow Servant rule can be complete without acknowledging the role played by economic developments. The rule developed in an industrial context, and Fellow Servant problems came before the courts because the machines of a rapidly industrializing society were maiming ever-growing numbers of employees. ${ }^{19}$ Moreover, the response of judges like Shaw, when faced with Fellow Servant cases, was undoubtedly influenced by the consequences that they recognized their decision would have for the economic and social developments they wished to foster. ${ }^{20}$

Such an explanation, however, while necessary, is not sufficient to explain the development of the Fellow Servant rule as it traveled through the American jurisdictions. By the late nineteenth century, the rule varied from state to state; its hallmark was not consistent subsidization of economic growth, but rather incoherence and inconsistency. ${ }^{21}$

${ }^{17}$ See, e.g., Coon v. Syracuse \& U.R.R., 6 Barb. 231, 236 (1849), affd, 5 N.Y. 492 (1851).

${ }_{18}$ See infra notes $102-06$ and accompanying text.

19 See Friedman \& Ladinsky, supra note 5, at 60 .

${ }^{20}$ See L. Levy, supra note 15, at 178-79; C. WARREN, A History of THE AMERICAN BAR 486 (1911).

${ }^{21}$ The Fellow Servant rule, in many jurisdictions, had developed into such a maze of conflicting rules, exceptions, and qualifications that no lawyer could confidently advise a client as to the exact state of his liability. See infra notes 148-224 and accompa- 
These developments, the Comment concludes, cannot be explained as a judicial response to economic needs within society at large, but were dependent far more on intellectual imperatives within the legal community. Many of Shaw's colleagues on the early nineteenth-century bench were not instrumentalists. Because they framed their responses to the rule within the constraints imposed by prevailing legal norms and techniques, they developed rules for their jurisdictions that produced shortterm legal harmony at the expense of long-term legal coherence.

\section{The Development of the Rule}

\section{A. Priestley v. Fowler, and its Influence upon American Courts}

It is not strange that economic determinists detected a conspiracy to aid the industrial classes in the Fellow Servant rule because the law out of which the rule developed had definitively imposed liability on a master for the consequences of a servant's negligence. In the eighteenth century, the rule of respondeat superior was extremely broad and firmly entrenched. As one of the earliest compilations of American law restated the rule: "the master is responsible for the acts of his servant, if done by his command, expressly or impliedly given."22 There were few exceptions to the rule, noted one treatise writer, for the law imposed upon the master the absolute duty to "employ servants who [were] skilful and careful."'2s

This broad principle could have covered the situation in which an employee negligently inflicted an injury, not upon a stranger, but upon a fellow employee. ${ }^{24}$ In France the high court of appeal did rule that respondeat superior was the principle applicable to Fellow Servant sit-

nying text. Treatise writers worried about the "extraordinary diversity of judicial opinion ... without a parallel in any department of jurisprudence." 4 C. LABATT, Master and Servant 4143 (2d ed. 1913). Another noted, "He must be a bold man who would undertake to tell where the doctrine of common employment [the Fellow Servant rule] ends, and that of the master's duty . . . begins in any State in the Union." Shirley, The Future of Our Profession, 17 AM. L. Rev. 645, 662 (1883). The litigation on the subject was enormous and the economic benefit of the rule to any class in society, except possibly the lawyers, was doubtful. In a widely used digest at the turn of the century, for example, the cases on a master's liability for injuries caused by negligent fellow servants consumed 750 pages. See 34 AM. Dig. 839-1588 (Century ed. 1902).

222 N. Dane, General Abridgment and Digest of American Law 494 (1823); see also T. Reeve, The Law of Baron and Femme, of Parent and Ghild, Guardian and Ward, Master and Servant and of the Powers of Courts of Chancery $357-58$ (2d ed. 1846); J. Story, Commentaries on The LAw OF AgENCY $\S 452$ (1839). The rule, in fact, was a prime example of liability arising out of predetermined status relationships, or contract, which was a characteristic of 18th century law. Cf. M. HoRwitz, supra note 1, at 207-08.

${ }^{23}$ T. REEVE, supra note 22 , at 358.

24 See Friedman \& Ladinsky, supra note 5, at 52-53. 
uations, ${ }^{25}$ and the United States Supreme Court came close to the same result in Philadelphia \& Reading Railroad $v$. Derby. ${ }^{26}$

The plaintiff in Derby was a stockholder of the defendant railroad company who was injured by the negligent conduct of the train engineer while riding on an official company tour. One argument advanced by the defendants was that the master is not liable for injury inflicted negligently by one servant upon another. ${ }^{27}$ The Court stated, however, that the cases cited by defendants "[have] no application to the present."'28 “[T]he maxim of 'respondeat superior,' which, by legal imputation, makes the master liable for the acts of his servant, is wholly irrespective of any contract, express or implied, or any other relation between the injured party and the master."20

Nevertheless, by the end of the eighteenth century, English and American courts had begun to set some limits to a master's liability for his servant's negligence, especially in those situations where the master actually exercised little control over the servant's behavior. He would not be held liable, for example, for a servant's willful, as opposed to negligent, wrong. ${ }^{30}$ Similarly, there were limits placed upon the extent of a shipowner's liability for the captain's negligence. Both limitations had as their rationale the protection of the master/servant relationship.

${ }^{28}$ The respondeat provision of the French Civil Code is the broadly phrased Article 1384. CODE CIVIL ART. 1384. The Cour de cassation, the high court of appeal, held in 1841 that respondeat definitely covered negligent injuries inflicted by one servant upon another, and rejected all argument that the master's liability under the law could be mitigated by a servant's "assumption of risk" implied in his rate of wages. See Reygasse v. Plazon, June 28, 1841, Cour de cassation, 1841 Recueil Periodique et Critique [D.P.] I 273. It is interesting to note that the case arose out of a domestic situation similar to that in Priestley v. Fowler, 150 Eng. Rep. 1030 (1937). In Reygasse the injury occurred when two gardeners were trimming a hedge. See infra notes 33-49 and accompanying text.

2855 U.S. 467, 14 How. 468 (1852).

27 Id. at 484. For this proposition the defendants cited Farwell v. Boston \& W.R.R., 45 Mass. (4 Met.) 49 (1842). Id.

2855 U.S. at 484,14 How. at 484.

2855 U.S. at 484,14 How. at 485 . In using such broad language the Court did not, however, state that the particular facts of the case before it presented a Fellow Servant situation, and thus did not expressly hold that respondeat was the principle applicable to such situations. The Court did state, however, that respondeat was applicable to the following situations:

If one be lawfully on the street or highway, and another's servant carelessly drives a stage or carriage against him, and injures his property or person, it is no answer to an action against the master for such injury, either, that the plaintiff was riding for pleasure, or that he was a stockholder in the road, or that he had not paid his toll, or that he was the guest of the defendant, or riding in a carriage borrowed from him, or that the defendant was the friend, benefactor, or brother of the plaintiff.

55 U.S. at 484-85, 14 How. at 485.

so See 2 N. DANE, supra note 22, at 494-95. 
The law could not, courts held, "allow to servants a power to ruin their masters." "91

A similar spirit animated Lord Abinger, sitting in the Court of Exchequer, when in 1837, he announced the court's decision in Priestley $v$. Fowler, ${ }^{\mathbf{2}}$ the case which first enunciated the Fellow Servant rule. ${ }^{33}$ Priestley was an unlikely case to carry its heavy precedential burden. Fowler, a butcher, ordered his assistant Priestley to make deliveries in an overloaded van driven by another assistant. The van capsized, fracturing Priestley's leg. He sued his master for damages, won, and the master appealed. ${ }^{34}$

Lord Abinger's opinion is scarcely a model of judicial clarity or authority. ${ }^{36} \mathrm{He}$ began by making the questionable decision to treat the case as one of first impression, which he was "therefore to decide ... upon general principles."36

One general principle relied upon by Abinger was assumption of risk. During the argument at court, Abinger stated that " $t]$ he plaintiff was not bound to go by an overloaded van; he consents to take the risk." In his opinion for the court, he stated that "the plaintiff must have known as well as his master, and probably better" about the dangerous condition of the van. ${ }^{38}$ He noted that " $[t]$ he servant is not bound to risk his safety in the service of his master and may, if he thinks fit, decline any service in which he reasonably apprehends injury to

31 Id. at 495. The eighteenth-century master/servant relationship was one based upon status and social ties rather than on economics. See M. Glendon, THE NEw Family and the New Property 146-47 (1981).

32150 Eng. Rep. 1030, 1032 (1837).

s3 See Friedman \& Ladinsky, supra note 5, at 54; Smith, supra note 9, at 259. But see Ingman, The Rise and Fall of the Doctrine of Common Employment, 1978 JURID. REv. 106 (claiming that the doctrine of common employment must be traced not to Priestley, but to subsequent cases which misread Priestley).

st 150 Eng. Rep. at 1030-31.

ss One authority considers much of the reasoning in the case to have been "far fetched" and cites it as a prime example of an incorrectly decided case. See R. CRoss, PReCEDENT IN ENGLISH LAW 191-92 (2d ed. 1968); see also Ingman supra note 33, at 108-10.

36 150 Eng. Rep. at 1032 . Ingman notes that the case could easily have been decided by reference to cases on the ill-treatment of apprentices, health and welfare of servants, or working condition of seamen. See Ingman supra note 33, at 109. The plaintiff's lawyer, in fact, argued the case strictly in terms of respondeat. See $150 \mathrm{Eng}$. Rep. at 1031.

37150 Eng. Rep. at 1031.

ss Id. at 1033. During argument Abinger had stated that "[i]t does not appear on the face of the declaration, that the plaintiff knew the van was overloaded, and it cannot be intended after verdict: on the other hand, it does not appear that the defendant knew it." Id. at 1031. The report of the case, however, notes that the plaintiff had given evidence at trial that the van had "been overloaded with the defendant's knowledge." Id. 


\section{himself."38}

Abinger also rested his decision upon general principles of public policy. He stated that a servant had a duty to exercise "diligence and caution" to protect himself from the negligence of a fellow servant, and that allowing the plaintiff to recover would discourage the exercise of that caution. ${ }^{10} \mathrm{He}$ concluded that "diligence and caution . . . are a much better security against any injury the servant may sustain by the negligence of others engaged under the same master, than any recourse against his master for damages could possibly afford."41

Perhaps the true basis of Lord Abinger's opinion lies in his "parade of horrors"-the consequences he feared would ensue from holding the master liable. Should Priestley recover, he warned, "the principle of that liability will be found to carry us to an alarming extent." ${ }^{\text {"42 }}$ He predicted,

The master, for example, would be liable to the servant for the negligence of the chambermaid, for putting him into a damp bed; for that of the upholsterer, for sending in a crazy bedstead, whereby he was made to fall down while asleep and injure himself; for the negligence of the cook, in not properly cleaning the copper vessels used in the kitchen; of the butcher, in supplying the family with meat of a quality injurious to the health; of the builder, for a defect in the foundation of the house, whereby it fell, and injured both the master and the servant by the ruins. ${ }^{43}$

Priestley, as Abinger's feared consequences demonstrate, grew out of a desire to preserve the eighteenth-century master/servant relationship. ${ }^{44}$ It decided no more than that an employee was considered to have assumed the risks of which he was aware, or that were obvious. As an English commentator noted, there was no need to extend the case into the industrial context, nor to read it as creating a broad rule exempting all employers from liability for negligent injuries among coworkers. ${ }^{45}$ Nevertheless, American courts gave Priestley this broad

s9 Id. at 1032-33; see also Ingman, supra note 33, at 110 ("Priestley $v$. Fowler decided that an employee, on taking employment, is deemed voluntarily to have accepted the risks incidental to the work and of which he is aware or which are obvious.").

40 150 Eng. Rep. at 1033.

41 Id.

12 Id. at 1032.

${ }^{43}$ Id.

4. See supra note 31 .

45 Ingman, supra note 33, at 110 . Smith regards the decision as "appropriate to a simple pre-industrial society." Smith, supra note 9, at 259 . Ingman notes that the ex- 
reading.

Although the industrial contexts of most American cases did not provide good factual analogies to Priestley's master/servant situation, ${ }^{\mathbf{4 8}}$ Priestley was continually cited in America for the broad proposition that an employer should not be liable for negligent injuries inflicted by one of his employees upon another. ${ }^{47}$ Even those judges who struggled to narrow the rule's application felt compelled to explain at length why Priestley's rationale did not cover the case before the court, rather than simply distinguishing the case on its facts, or dismissing it as unauthoritative "foreign" authority. ${ }^{48}$ What, then, explains the continuing disposition of American courts to acknowledge the authority of this recent English decision?

One explanation has been given by Friedman and Ladinsky. Priestley, in their view, remained authoritative simply because its principle of restricting an employer's liability filled a need in an industrializing America: "Had there been no Priestley v. Fowler, it would have been necessary-and hardly difficult - to invent one."48

An alternative explanation, which accords better with what courts did, rather than what they might have done, recognizes the continuing authority of English precedent in mid-nineteenth-century American courts. This explanation, however, conflicts with one central proposition of the Horwitz thesis. For Horwitz, the transformation of American law depended upon a rejection by instrumentalist judges of the constraints of English form and authority and an acceptance instead of a style of judicial reasoning which was "derived from a new conception of common law as a self-conscious instrument of social policy."

tension of the Priestley rule to cover negligence of fellow servants in an industrial context did not come about in England until 1850, in Hutchinson v. York, N. \& B. Ry., 155 Eng. Rep. 150 (1850). See Ingman, supra note 33, at 114. In Hutchinson the rule was broadly stated (and imputed to Priestley) that a servant "when he engages to serve a master, undertakes . . . to run all the ordinary risks of the service, and this includes the risk of negligence on the part of a fellow-servant." Hutchinson, 155 Eng. Rep. at 154. This explanation will not account for the authority Priestley had in America, however, where it was cited to support the broad Fellow Servant principle both before and after 1850. See, e.g., Scudder v. Woodbridge, 1 Ga. 195, 198 (1846); Coon v. Syracuse \& U.R.R., 6 Barb. 231, 235 (1849), affd, 5 N.Y. 492 (1851); Ponton v. Wilmington \& W.R.R., 51 N.C. (6 Jones) 245, 246 (1858); Ryan v. Cumberland Valley R.R., 23 Pa. 384,386 (1854).

46 It has been argued that Priestley was also inappropriate to rapidly industrializing mid-nineteenth century Britain. See Smith, supra note 9, at 259.

17 See, e.g., Coon v. Syracuse \& U.R.R., 5 N.Y. 492, 494 (1851); Ryan v. Cumberland Valley R.R., 23 Pa. 384, 386 (1854).

48 See, e.g., Gillenwater v. Madison \& I.R.R., 5 Ind. 339, 343-44 (1854).

49 Friedman \& Ladinsky, supra note 5, at 55.

so M. Horwitz, supra note 1, at 25. See id. at 22-26; see also Nelson, The Impact of the Antislavery Movement upon Styles of Judicial Reasoning in Nineteenth 
dence, Horwitz relied on state statutes forbidding the continued citation of recent English cases and on statements by American scholars that much of English common law was "as inapplicable to [American] concerns as the laws of Germany or Spain."

In fact, such evidence may prove only that the fears of those jurists who wished to free American law from common law constraints were well grounded. American lawyers, despite the best efforts of these reformers, remained wedded to the English sources of authority that their training had taught them to revere. ${ }^{62}$ As the Philadelphia lawyer Charles Ingersoll complained, "American lawyers and judges adhere with professional tenacity to the laws of the Mother Country." "Recent English adjudications," he noted, were "received with a respect, too much bordering on submission." He deplored the "professional bigotry" which led to the acceptance of these authorities "without probation or fitness."

This continuing hold of English authority is not surprising. The apprenticeship training of most American lawyers practicing in the early nineteenth century depended heavily upon an almost ritual reading of English authorities; ${ }^{\text {st }}$ English opinions were the standard by which lawyers judged the products of American courts, ${ }^{\mathrm{sb}}$ and the professional conduct of the English bench and bar was held up as the model for the profession. ${ }^{86}$

The continuing weight given precedents of authoritative English

Century America, 87 HARv. L. Rev. 513, 514 (1974). See generally Scheiber, Instrumentalism and Property Rights: A Reconsideration of American 'Styles of Judicial Reasoning' in the 19th Century, 1975 WIS. L. REv. 1, 4.

81 1 N. DANe, supra note 22, at v; see M. HorwrTz, supra 1, at 1-30.

62 This was precisely what Scheiber found regarding American riparian law: "[f]ar from rejecting common-law precedents out of hand, American judges felt constrained to cast emergent riparian law in the traditional framework." See Scheiber, supra note 50, at 5. These judges, he notes, "often bent far to adopt outright-or at least to acknowledge the basic validity of "ancient English . . . authorities." See id. (footnote omitted); see also L. Friedman, supra note 5, at 285.

ss C. Ingersoll, A Discourse Concerning the INFLUence of AMERICA ON THE Mind (1823), cited in C. WARREN, supra note 20, at 509; see also Shirley, supra note 21, at 658 ("Our courts constantly turn to the reports of the mother country and her dependencies."); Law Reform-Practice, 12 MonTHLy L. REP. (n.s. No. 2) 61, 71 (1849).

s4 See 2 A. Chroust, The Rise of the Legal Profession in America 175 76,288 (1965).

os Cf., e.g., Story, Progress of Jurisprudence, An Address Delivered Before the Members of the Suffolk Bar (1821), in The Miscellaneous WRITINGs OF JosePH STORY 198, 233 (W. Story ed. 1852) ("[E]xemplifications of our judgments may pass . .. to England; and it ought to be our pride to know, that they will not be disgraced under the inspection of the sober benchers of any Inn of Court.").

See, e.g., The Bench and Bar in England, 12 MonTHLy L. REP. (n.s. No. 2) 217,223 (1849). 
courts had an important influence on the development of the Fellow Servant rule in America. Beginning with almost the first case, defendants' counsel cited Priestley's holding as persuasive authority for the proposition that a master was not liable in damages to his servant for injuries caused by a fellow servant. ${ }^{57}$ American courts disposed to reject the Fellow Servant rule could do so only by rejecting or lessening the force of a decision of the English Court of Exchequer. ${ }^{58}$

\section{B. Farwell v. Boston \& Worcester Rail Road: Establishing the Rule in America}

The first American cases to adopt the Fellow Servant rule were Murray v. South Carolina Railroad ${ }^{50}$ and Farwell v. Boston $\mathcal{E}^{\circ}$ Worcester Rail Road. ${ }^{60}$ Both cases involved railroad accidents, which would come to be the typical Fellow Servant context. ${ }^{61}$ Both cases squarely held that masters would not be held liable for negligent injuries inflicted by one employee upon another. Yet Farwell is regarded by most authorities as the case which established the Fellow Servant rule in America.$^{62}$ Murray, decided four years before Farwell, faded quickly into relative obscurity. Murray, a divided opinion, weakly reasoned, from a little-regarded state court, epitomized the type of case authority

${ }^{87}$ See, e.g., Scudder v. Woodbridge, 1 Ga. 195, 196 (1846); Farwell v. Boston \& W.R.R., 45 Mass. (4 Met.) 49, 54 (1842).

${ }^{68}$ One way to do so was to counter the weight of Priestley with authority from another common law jurisdiction, Scotland. In Dixon v. Rankin, 1852 Sess. Cas., 14 D. 420 , the Scots Court of Sessions decisively rejected the Priestley doctrine. "If this be the law of England ...." held Lord Cockburn, "it most certainly is not the law of Scotland." He was glad of it, he observed, because he had "rarely come upon any principle that seem[ed] less reconcileable to general legal reason." If servants did assume any risk, they did so on the master's account, and in justice the master should be liable for harm. 14 D. at 426.

Dixon was reprinted in America in one of the first specialized unofficial reporters. See 1 AM. R.R. CASES 569 (1852). The reasoning was cited by American authorities to counter Priestley's weight, although the case was not followed. See, e.g., Bassett v. Norwich \& W.R.R., 19 MonThly L. REP. (n.s. No. 9) 551 (1857); Gleveland, C. \& C.R.R. v. Keary, 3 Ohio St. 201, 213 (1854).

s8 26 S.C.L. (1 McMul.) 385 (1838).

6o 45 Mass. (4 Met.) 49 (1842).

o1 The Fellow Servant rule was not necessarily limited to railroad accidents. See, e.g., Albro v. Agawam Canal Co., 60 Mass. (6 Cush.) 75, 77 (1850) (Farwell cited as governing authority for absolving the owner of a cotton mill from liability). Nevertheless, most cases of first impression arose in a railroad context, and the rule itself was considered, at least by many treatise writers, as a part of railroad law. See I. REDField, A Practical Treatise upon the Law of Railways 386-92 (2d ed. 1858); H. Pierce, A Treatise on American Railroad Law 286-310 (1857); see also Friedman \& Ladinsky, supra note 5, at 60 . Because one can trace the rule's development solely within the railroad context, the wider application of the rule is beyond the scope of this Comment.

${ }^{62}$ See, e.g., C. WARREN, supra note 20 , at 485; L. LeVY, supra note 15, at 167. 
nineteenth-century courts, were least disposed to follow. ${ }^{63}$ Farwell was just the opposite.

Farwell $^{64}$ came before Chief Justice Lemuel Shaw of the Supreme Judicial Court of Massachusetts in March 1842.65 The facts presented a sympathetic case for the plaintiff. Farwell was an engineer on the new Boston \& Worcester. While the engineer was driving his engine with all due care, the train jumped the track because a depot employee had neglected to throw the appropriate switch. Farwell was "thrown with great violence upon the ground" and his right hand was crushed under the passing railroad car. ${ }^{66}$

Counsel for both plaintiff and defendants presented a narrow case to Shaw for decision. Plaintiff's counsel conceded that respondeat did not cover the case, and that Priestley, which had been "rightly decided," was the relevant precedent. ${ }^{67}$ He believed, however, that his client's case must be distinguished because an engineer and a switch tender did not share a "common purpose," and therefore could not be considered to be "fellow servants." Defendants' counsel, predictably,

63 See infra notes 106-10 \& 141-46 and accompanying text. The first American plaintiff to be confronted by the Fellow Servant rule was James Murray, a former tailor of "intemperate habits" who had taken work as a fireman on one of South Carolina's first steam railroads. Murray, 26 S.C.L. (1 McMul.) at 385. When the engineer negilgently ran the train into a horse, Murray's leg was crushed between the engine and tender. The factual situation was confused, however, and it was not clear whether Murray's injury had resulted from a fellow servant's negligence. See id. at 402 (O'Neall, J., dissenting).

The court divided, 7-3. The majority opinion is a model of judicial hesitation and timidity. The court relied heavily on the fact that there was no precedent for holding an employer liable. Although the railroad's liability to its passengers as a common carrier was clear, the court refused to extend liability to the railroad, as employer, "without a single case or precedent to sustain it." 26 S.C.L. (1 McMul.) at 400. The court ended on a tentative note, issuing an invitation to subsequent courts to narrow Murray's holding to the facts of the case. It was "not intended," the court observed, "to prejudge other questions, which may arise between the company and its servants," nor did it consider Murray to settle the question in future cases of "whether an individual or company will be liable for the acts of one agent to another." Id. at 401 .

The tentative nature of the majority contrasted sharply with the two strong dissents, which agrued that respondeat fully covered the case. Surely, one dissenting justice observed, no one would "presume" to "contend that the rule applicable to service in a rail road company, is, that the company is not liable to any agent, for any injury, provided the company can only shew that another of its agents has inflicted it." Id. at 408 (Johnston, J., dissenting). In fact, within one year of Murray, Chief Justice Shaw of Massachusetts "presumed" to contend for a rule precisely this broad. Compare the authoritative nature of Shaw's Farwell opinion, infra text accompanying notes 109-14.

or 45 Mass. (4 Met.) 49 (1842).

65 On Shaw himself, see the excellent biography by L. LEVY, supra note 15.

ob 45 Mass. (4 Met.) at 50.

${ }^{67}$ Id. at 52 .

68 45 Mass. (4 Met.) at 51 (plaintiffs argument). One might argue that it was an inexcusable tactical error for plaintiff's counsel, Loring, to have conceded that respondeat was not applicable. Horwitz, in fact, labeled Loring's concession as "astonishing." 
argued that Murray and Priestley precisely covered the case, but that, in any event, it would "not be necessary for the court to lay down a general rule, in order to decide this case for the defendants."

The arguments of counsel are particularly interesting because they demonstrate clearly the narrow way in which Farwell might have been decided by a judge other than Shaw. They epitomize the model of decision in fact followed in later Fellow Servant cases. ${ }^{70}$

Shaw, however, viewed the case in a much broader light and selfconsciously laid out and justified a general rule for regulating a - master's liability for negligent injuries inflicted by employees upon their co-workers. He framed the question for decision in the broadest possible terms. "The question is," he noted, "whether, for damages sustained by one of [a railroad's employees] by means of the carelessness and negligence of another, the party injured has a remedy against the common employer."'71

Shaw's Farwell opinion is well known and his reasoning has been extensively analyzed. ${ }^{\mathbf{7 2}} \mathrm{He}$ simply brushed away any suggestion that the case could be decided by extending respondeat, with a grateful nod to plaintiff's counsel for conceding the point, ${ }^{73}$ and proceeded to justify his rule on the intertwined theories of implied contract and assumption of risk. When a servant voluntarily accepts employment, Shaw concluded, he assumes all risks "incident" to his employment, among which must be included the risk of "carelessness and negligence of those who are in the same employment." Such a rule best ensures industrial safety, Shaw reasoned, for it gives employees, who are in the best position to observe and guard against their co-workers' negligence, the incentive to do so. ${ }^{75}$

A striking aspect of Farwell, to a modern observer, is its self-consciousness. Shaw was acutely aware that he was creating law. He stated his conclusions broadly, and dismissed any attempts to narrow

M. HoRwrTz, supra note 1, at 210. While the concession made Shaw's opinion easier to write, Loring was only following a perfectly acceptable model of lawyering, that is, conceding the general point, and attempting to distinguish his client's case. Such tactics were in no small measure responsible for the rapid spread of the Fellow Servant rule. See infra text accompanying notes 217-22.

69 Mass. (4 Met.) at 54 (defendant's argument).

${ }^{70}$ See infra text accompanying notes 120-224.

7145 Mass. (4 Met.) at 55.

72 See, e.g., L. FRIEDMAN, supra note 5, at 263-64, 414; M. HorwITz, supra note 1 , at 209-10; R. Pound, supra note 13 , at 87.

7345 Mass. (4 Met.) at 56.

74 Id. at 57 .

75 Id. at 59; cf. Priestley, 150 Eng. Rep. at 1033 ("To allow this sort of action to prevail would be an encouragement to the servant to omit that diligence and caution which he is in duty bound to exercise on the behalf of his master ...."). 
his rule as "supposed distinctions" on which "it would be extremely difficult to establish a practical rule." ${ }^{\text {"76 }}$ This self-consciousness is apparent in Shaw's cavalier reference to the only precedents which existed, Priestley and Murray. ${ }^{77}$ In contrast to his elaborate exposition of his assumption of risk and implied contract theories, Shaw simply observed that the "authorities, as far as they go," supported his position. ${ }^{78}$

The premises upon which Farwell rested reflected accurately the precarious reality of the early railroads. While recent scholarship has cast doubt on the key role of railroads in fueling nineteenth-century economic growth ${ }^{79}$ there is little doubt that contemporaries enthusiastically supported the new mode of transportation as a boon to enterprise. The economic position of the early railroads, however, was uncertain; railroad supporters worried about the ability of the roads to surmount the twin obstacles of uncertain financing and a rudimentary technology. ${ }^{80}$ A recent study of the early years of the Boston \& Worcester Railroad, the defendant in Farwell, graphically depicts the realities of the early railroads. The trains ran along a single track, with no signals, and, initially, no way of warning scheduled passenger trains of the presence of repair trains on the track. ${ }^{8 x}$ The directors attempted to minimize the danger through a system of rigid scheduling and elaborate safety rules, the necessity to obey which was pressed upon the employees. ${ }^{82}$ The wages paid employees charged with the responsibility of enforcing these rules were considerably higher than those paid to lower level employees. ${ }^{8 s}$

The entrepreneurs who owned the railroads, then, were interested in reducing safety hazards as well as in turning a profit. ${ }^{84}$ Shaw responded well to their concerns when in Farwell he relieved the rail-

26 45 Mass. (4 Met.) at 60.

77 Although he referred to Priestley in a slighting manner, Shaw nonetheless rested his decision on the same assumption of risk argument used by Lord Abinger. See supra notes 73-74 and accompanying text.

7845 Mass. (4 Met.) at 57.

79 See, e.g., R. Fogel, RaIlroads and American Economic Growth: EsSAYS IN ECONOMETRIC HISTORY 15 (1964).

so See, e.g., S. Salsbury, The State, the Investor, and the Railroad: The Boston \& AlBany, 1825-1867, at 81-82 (1967).

81 "Miraculously, however, no scheduled train ever collided with another during the early years. The railroad's wrecks all involved an unscheduled repair train, which emerged as the system's Jonah." Id. at 115.

${ }_{82}$ Id. at 113-19. See generally A. Chandler, JR., Strategy and Structure: Chapters in the History of THE Industrial ENTERPRISE 21-23, 38 (1962).

${ }^{83}$ See S. SAlSBURY, supra note 80, at 359 n.7. Conductors, who ran the trains, received $\$ 600$ yearly; engineers, who drove them, received $\$ 2$ per day; and firemen and brakemen received $\$ 1$ respectively.

84 The Boston \& Worcester's board of directors had created a rate structure which they had originally hoped would produce a six per cent annual dividend. Id. at 123. 
roads of potentially massive liability for Fellow Servant injuries and thereby placed the burden of avoiding accidents on the employees who were already paid to prevent them.

Shaw, then, by attending so well to the needs of the entrepreneurial classes, ${ }^{85}$ is the very model of Horwitz's instrumentalist judge. Because many of his contemporaries on the American bench and bar were motivated by far different imperatives, however, they simply followed Farwell as precedent, rather than emulating Shaw's style and examining his premises.

\section{Following Farwell: Jurisprudence by Discovery}

With the spectacular growth of railroads in the 1840 's ${ }^{86}$ came the predictable rash of railroad accidents. One American jurisdiction after another faced the question whether to adopt the Fellow Servant rule. Many recognized that it was "a question of very great importance, from the frequency with which accidents of that kind are liable to happen upon the numerous railroads of the state." ${ }^{187}$ Most courts decided to follow Priestley and Farwell and broadly adopt the rule.

New York was typical. A lower court had declined an opportunity to adopt the rule in $1844^{88}$ and the question did not reach an appellate court until 1849 in Coon v. Syracuse S Utica Rail-Road. $^{89}$ The plain-

85 C. WARREN, supra note 20 , at 449 . Warren observed that Shaw had been "largely influenced by economic conditions and the need of favoring the young and struggling institution of railroads."

There is an intriguing question of just how personally Shaw was acquainted with the Boston \& Worcester. In his papers is a letter dated February 28, 1842 from George Bliss, founder, director, and newly elected president of the railroad. Bliss invited Shaw and "other members of the Supreme Court" to accompany the company's directors and executive officers on "an excursion to Springfield on Friday the 4th ... to meet the public authorities of $\mathrm{N}$. York including their Judiciary." With the letter is a ticket, made out "For Chief Justice Shaw" for a return fare, Boston to Albany, on March 4, 1842. There is no indication whether Shaw made the trip. Farwell was decided at the March 1842 term. See Letter from George Bliss to Lemuel Shaw (Feb. 28, 1842) (Lemuel Shaw Papers, Reel XII, No. 762, Univ. of Va. Library). On Bliss, see S. SALSBURY, supra note 80 at 182.

${ }^{8 B}$ Between 1830 and 1848 , there was a total of 5,205 miles of track built in the United States. Between 1849 and 1860, 30,135 miles were built. See C. WARREN, supra note 20 , at 479 . (1851).

${ }^{87}$ Coon v. Syracuse \& U.R.R., 6 Barb. 231, 236 (1849), affd, 5 N.Y. 492

${ }_{88}$ In Brown v. Maxwell, 6 Hill 592, 594-95 (N.Y. Sup. Ct. 1844), the court referred to the "recently adjudged" Farwell decision which, though "thoroughly examined and considered" and of which the court entertained "no doubt of [the] correctness," was not necessary to a decision of the instant case, which was decided on a theory of contributory negligence.

896 Barb. 231 (1849). Coon, decided in an appellate division of the Supreme Court (New York's lower court) will be considered the case of first impression in New 
tiff, a track repairman operating a hand car, was "run over" by a repair train. ${ }^{00}$ While the case presented questions of contributory negligence, ${ }^{\theta 1}$ the court ignored them and rested its opinion squarely on Priestley and Farwell, in which "the subject . . . would seem to be exhausted." "[I]t would be presumption in me," Judge Pratt wrote, "to attempt to add anything to the force of those decisions, by way of argument or illustration." 92 His opinion closely followed Shaw's implied contract theory, and adverted to Lord Abinger's examples in discussing the policy consequences of a contrary rule. ${ }^{93}$ Coon is striking, and typical, in the unqualified manner in which it adopts the Fellow Servant rule. On the authority of Farwell, Pratt simply dismissed any possible limitations on the rule. ${ }^{94}$ The New York Fellow Servant rule, therefore, came close to exempting employers from all liability for industrial accidents caused by an employee's negligence.

Other jurisdictions emulated the New York approach; some opinions did no more than observe that the question was a new one in the state, that "the whole argument upon the question is embodied in the opinion of Chief Justice Shaw," and that therefore the rule must be

York. The presiding judge, Pratt, treated it as such, and was explicit about his reasons for adopting the broad Fellow Servant rule. Pratt was strongly reaffirmed by the New York Court of Appeals, in a two-page opinion, in which two justices, Gardiner and Foot, held that the lower court had rightly followed Farwell. See 5 N.Y. 492, 495 (1851) (Gardiner, J.) ("The case before us cannot be distinguished from that in Metcalf. To the elaborate opinion of chief justice SHAW, nothing can be added without danter of impairing the force of his reasoning."). The separate opinion of Justice Foot was even blunter:

Was [sic] this principle sought to be applied for the first time in the present action, I should deem it my duty, not only to examine it in all its bearings, test its soundness by all the means at my command, and endeavor to reach a correct conclusion, but also to assign in full my reasons. This duty has, however, been already performed, ably and learnedly, by three eminent judicial tribunals: viz, the court of exchequer in England [Priestley], the court of appeals of South Carolina [Murray], and the supreme court of Massachusetts [Farwell] [citations omitted]. They all concur in sanctioning the principle, and I fully acquiesce in their judgment . . .. It must now be considered as settled, and hereafter to form a part of the common law of the country.

Id. at 496. So, in fact, it was treated in the next Fellow Servant case to reach the Court of Appeals. See Keegan v. Western R.R., 8 N.Y. 175, 180 (1853).

6 Barb. at 231.

91 Counsel for the defendants argued that plaintiff had a "duty to carry a light, so that ... he might be seen by the engineers." Id. at 235 . The court agreed: "The evidence ... shows quite clearly that the plaintiff was himself guilty of negligence ...."Id.

22 Id. at 236.

9s Id. at $239-40$.

ot Id. at 241, 242-43. Thus, for example, Pratt turned aside arguments which would have created exceptions in the case of negligent superiors or workers in different departments. On these exceptions, see infra text accompanying notes 148-204. 
adopted. ${ }^{95}$ As more jurisdictions followed this pattern, the string citations following the adoption of the rule became longer. ${ }^{96}$

Some scholars have simply correlated the adoption of the broad rule in so many jurisdictions with the contemporaneous rapid expansion of railroads. ${ }^{97}$ The two phenomena undoubtedly coincided. ${ }^{88}$ It is also true that railroad accidents provided the factual context for most Fellow Servant cases. ${ }^{90}$

Any such explanation, however, standing alone, is insufficient. Some jurisdictions that followed the rule were highly developed railroad states, but others were not. Moreover, some jurisdictions that struggled against the rule had a heavy concentration of railroads. ${ }^{100}$ While it would be wrong to ignore the role played by railroads in providing both the occasion, and, in some instances, the impetus for judges to adopt the Fellow Servant rule, such an explanation cannot explain the differences in the rule adopted by jurisdictions exhibiting a generally similar pattern of railroad development.

A plausible explanation for these results is that vastly divergent legal styles coexisted in the nineteenth century and created the mass of

9s Honner v. Illinois Cent. R.R., 15 Ill. 550, 552 (1854). Honner is an extreme example, a two-page opinion, half of which is taken up by a recitation of the facts. See also Ryan v. Cumberland Valley R.R., 23 Pa. 384 (1854).

Though this proposition has never been decided upon by this Court, it has often been considered elsewhere and decided in the negative .... Where we find a road is so well beaten, it is easy to follow it, and its beaten character is an indication that we may follow it with safety.

Id. at 386 .

86 See, e.g., Carle v. Bangor \& P. Canal \& R.R., 43 Me. 269, 270 (1857); O'Connell v. Baltimore \& O.R.R., 20 Md. 212, 221 (1863). The Maryland restatement is typical in its sweep: "When several persons are employed in the same general service, and one is injured by the carelessness of another ... the employer is not responsible. The liability to injury of one from the carelessness of his fellows, is but an ordinary risk against which the law furnished no protection ...." Id.

${ }^{97}$ Cf., e.g., C. WARREN, supra note 20 , at 485-87.

88 The first great era of railroad expansion was 1840 to 1860 . See supra note 86. Almost all American cases of first impression occurred within this time frame.

29 For variations, however, see Walker v. Bolling, 22 Ala. 294 (1853) (steamboat accident); Randolph v. Hill, $34 \mathrm{Va}$. (7 Leigh) 383 (1836) (mining accident).

100 For details of the narrow version adopted in two states, see infra notes 148204 and accompanying text. An 1873 compilation of railroad trackage and the number of incorporated railroad companies reveals few differences in development between those states which adopted the broad Farwell rule and those adopting a qualified version. For example, Illinois, which adopted the broad rule, had 47 companies and 6,620 miles of track; Ohio, which severly qualified the rule, had 42 companies and 4,050 miles of track. Similarly, Maryland, a broad-rule state, had 17 companies and 802 miles; Tennessee, a narrow-rule state, had 18 companies and 1,541 miles. Moreover, if one compares the incorporation dates of railroad companies in Ohio with those in Massachusetts, one notes that Ohio courts were adopting the narrow rule at the same time the legislatures in both states were furiously incorporating railroads. AMERICAN RAILRoAd Manual 460, 410, 280, 378 (E. Vernon ed. 1873). 
conflicting jurisprudence that was the Fellow Servant rule. That is, some judges may have been disposed to follow Priestley and Farwell not because they were instrumentalists attuned to economic developments within their jurisdictions as Horwitz would suggest, but rather because their training and intellectual bias required them to adhere to certain common law myths. This explanation requires recognition that instrumentalist judges like Shaw coexisted with judges like Pratt whose model of proper judicial behavior included adherence to these myths. ${ }^{101}$

According to these myths, the common law grew, slowly ${ }^{102}$ or quickly, ${ }^{103}$ out of the customs and practices of any particular society. The role of judges, in any particular case, was to "discover" what that rule or custom might be. ${ }^{104}$ To any particular legal question, the common law posited but one correct answer, and those judges who rightly "discovered" the correct rule were entitled to respect and adherence. ${ }^{105}$ These myths put a premium on judicial harmony and consistency across jurisdictions. A corollary of the concern for harmony was a rev-

101 Such an explanation also accounts for the peculier way in which judges framed their dissension to the rule, not by rejecting it, but rather by carving out wide "exceptions" which, in some cases, came close to swallowing the general rule. See infra text accompanying notes 120-224. A similar explanation is offered by H.N. Scheiber, who views instrumentalism and traditionalism as coexisting, not only within the same legal system, but within the same judges. See Scheiber, supra note 50, at 7 .

$102 \mathrm{~J}$. Wilson, Lectures at the College of Philadelphia (1791) in 1 Works of James WIIsON 335, 353 (R. McCloskey ed. 1967); see also 1 J. KENT, COMMENTARIES ON AMERICAN LAW 471 (12th ed. 1884) ("[a] great proportion" of the rules and maxims "grew into use by gradual adoption, and received, from time to time, the sanction of the courts of justice"). 447.

$103 \mathrm{~J}$. Wilson, supra note 102 , at 354; see also G. WARREN, supra note 20 , at

106 The maxim was stated by Blackstone: "the decisions of courts of justice are the evidence of what is common law." 1 W. BLACKSTONE, CoMmENTARIES 88-89, quoted in $\mathbf{R}$. CRoss, supra note 35, at 23 . This myth of judges as "discoverers" of the common law persisted far into the nineteenth century. A late nineteenth century law dictionary, in its definition of "common law," observed, "[t]he decision of a court which establishes or declares a rule of law may be reduced to writing and published in the reports; but this report is not the law; it is but evidence of the law." $1 \mathrm{~J}$. BouviER, LAw DictionARY 304 (14th ed. 1875). For an assertion that conceptions of common law as "discovered" and "made" by judges have always coexisted, see Simpson, The Common Law and Legal Theory, in OxFord Essays IN JuRISPRUDENCE 77, 81 (2d ser. 1973). For the persistence of the "discovery" myth, see F. Lawson, The Rational Strength of ENGLish Law 16-17 (1951).

${ }_{105}$ A review of a popular railroad treatise, I. REDFIELD, supra note 61 , observed that the emerging principles of railroad law were undoubtedly correct and "entitled to confidence" and "respect" owing to the "general uniformity which prevails in the decisions of these cases as they have arisen from time to time in the courts of some thirty different and independent States." Notices of New Publications, 20 MONTHLY L. REP. (n.s. No. 10) 533 (1858), cited in C. WARREN, supra note 20, at 492 n.1. Compare I. REDFIELD, supra note 61, at 389, where he notes the divergence between the Scots and English opinions on the Fellow Servant rule and observes, "it is always to be regretted, that any difference of decision should exist, among the tribunals of the different states." 
erence for unanimous opinions and a suspicion that divided courts had probably "discovered" wrongly. ${ }^{108}$

Horwitz has argued, however, that the old common law myths of judicial discovery and resultant harmony were discarded by nineteenthcentury judges as unwarranted constraints upon their ability to make new law. ${ }^{107}$ The Fellow Servant cases, however, including those in which the Farwell rule was broadly adopted, demonstrate that these myths did not disappear completely in the nineteenth century. ${ }^{108}$

Shaw's opinion in Farwell contained all the characteristics to indicate that its legal solutions were rightly discovered, and thus could be unquestioningly followed by subsequent courts. First, the opinions of certain judges carried more weight than others, and Shaw individually was preeminet. ${ }^{108}$ Moreover, as Chief Justice of the highest court of

${ }^{108}$ See, e.g., 1 N. DANE, supra note 22 , at vii (he had relied on only the best authorities, and therefore "not much reliance had been had ... on divided opinions"); The Citing of Authorities, 8 AM. JuRIST 111, 117 (1832) ("[c]ases ... upon which the court has divided, are to be little relied on as authorities, and sparingly cited").

107 M. HoRwrTz, supra note 1, at 1-30. Horwitz characterizes the common law myths described here as eighteenth-century conceptions, which were discarded by nineteenth-century judges who had "a new conception of common law as a self-conscious instrument of social policy." These judges believed the common law was not "rules or doctrines to be discovered, not ... customary norms to be applied through precedent" but rather "a body of prudential regulations framed . . . from the perspective of "enlarged and liberal views of policy." "Id. at 25-26. Horwitz' periodization, however, has been criticized. See, e.g., Simpson, supra note 10. It is a thesis of this Comment that the older conception of the common law survived into the nineteenth century, and that it was the interaction of the old and new styles of judicial reasoning which produced the Fellow Servant rule.

${ }^{108}$ These cases are also evidence of the fervent desire of courts to buttress their opinions by reference to some form of authority. Horwitz has posited that early nineteenth-century judges felt entirely comfortable in reasoning from "first principles," and discarding inappropriate precedent. See M. HoRwITz, supra note 1, at 24-26. The Fellow Servant cases offer evidence of precisely the opposite desire, not to contradict "well-settled" law. In only two cases was there any hint that a court felt free to contradict established authority. See infra text accompanying notes 157-64 \& 209-12. Much more typical was the attitude displayed by the editors of the American Jurist, one of the earliest legal periodicals, who reviewed new volumes of the Ohio Reports by citing approvingly the maxim "optima est lex, quae minimum relinquit arbitrio judicis, optimus judex, qui minimum sibi" ["that law is best which leaves least to the discretion of the judge; that judge is best who leaves least to his own"]. 7 AM JURIST 261 (1832).

109 Contemporaries self-consciously ordered authorities by referring to the source. Thus, Professor Greenleaf cautioned entering Harvard students in 1838 that one of the prime factors to consider in weighing authorities was "the position of the judges." Notes of Prof. Greenleafs Introductory Lecture, 1 LAw. REP. 217, 219 (1838) (hereinafter cited as Greenleaf). This, of course, remains true in the twentieth century. See R. Pound, supra note 13, at 86; Clark \& Trubek, The Creative Role of the Judge: Restraint and Freedom in the Common Law Tradition, 71 YAle L.J. 255, 260 (1961). Shaw was on most contemporary, as well as modern, lists of "great judges." See C. WARREN, supra note 20, at 448; see also 2 A. Chroust, supra note 54, at 284. One modern authority noted that Shaw "dominated the common law . . of that era." Ursin, supra note 9, at 259. 
Massachusetts, he spoke from a forum which, like the Court of Exchequer, commanded particular respect. ${ }^{110}$

Shaw's method of reasoning, furthermore, reinforced his authority. He had very carefully considered the nature of authoritative legal argument, ${ }^{111}$ and his Farwell opinion demonstrated his method. He clearly stated the theories of implied contract and assumption of risk upon which the opinion rested, considered the policy consequences of an alternative decision, drew proper analogies to existing law, and stated a broad and clear general rule for exempting a master from liability. ${ }^{112}$ This style of analysis carried great persuasive force, if not binding authority. Because the efficient new legal information system put this case quickly into the hands of railroad lawyers, ${ }^{113}$ subsequent judges would have been required to go to elaborate lengths to refute it. It was much easier to rule that Farwell "appear[ed] to have been thoroughly examined and considered," and therefore one need "entertain no doubt of its correctness."'114

Finally, as the years passed, and the number of decisions following Farwell began to mount, judges disposed to hold masters liable for negligent injuries committed by one servant upon another began to be overwhelmed by the sheer number of precedents against such liability. Railroad lawyers were quick to argue that the Fellow Servant rule was "well settled law."11s As early as 1853, a Pennsylvania lower court ruled that, even in the absence of a state supreme court decision, a master's liability could "scarcely be regarded as an open question; for

110 See 1 N. DANE, supra note 22, at vi; R. Pound, supra note 13, at 89 (noting that Massachusetts opinions were "followed as a matter of course"); see also L. FRIEDMAN, supra note 5, at 284.

111 See Shaw, Profession of the Law in the United States, 7 AM. JuRIST 56, 69 (1832) (address before the Suffolk Bar, May 1827). On Shaw's opinion style, see L. LEVY, supra note 15, at 22-26.

112 Shaw's style in fact paralleled that recently described by Cross as the model of persuasive reasoning in cases of first impression. See $\mathbf{R}$. CRoss supra note 35, at 19495.

113 See infra notes 139-47 and accompanying text.

114 Brown v. Maxwell, 6 Hill 592, 594-95 (N.Y. Sup. Ct. 1844) (Beardsley, J.); see Harrison v. Central R.R., 31 N.J.L. 293, 296 (1865) (Shaw's "argument of great force and clearness"); see also Honner v. Illinois Cent. R.R., 15 Ill. 550, 551 (1854) ("the whole argument upon the question is embodied in the opinion of Chief Justice Shaw"); I. REDFIELD, supra note 61, at 426 n.9 ("very lucid and convincing argument of Shaw Ch. J."). Following a well-considered opinion was considered a perfectly respectable course. Thus, one of the factors Professor Greenleaf cited to Harvard students in weighing authority was "the degree of consideration which the point may appear to have received." Greenleaf, supra note 109, at 22.

116 See, e.g., Little Miami R.R. v. Stevens, 20 Ohio 415, 422 (1851) (railroad's argument) ("It is well settled that the master is not liable for injuries sustained by one workman or servant by the careless or negligent or unskillful act of another workman or servant.") (emphasis in original). 
other Courts, of the highest respectability ... have considered and decided it." ${ }^{\text {"18 }}$ By 1861, courts spoke of the rule as one supported by an "unbroken current of judicial opinion,"117 upon which any tribunal, even in a case of first impression, could rely, thus "greatly relieving us from the responsibility of settling the law."118 Within twenty-five years of Priestley, therefore, even those judges disposed to question the correctness of the rule, clearly had to swim against a strong judicial tide to avoid adopting it. "[W]hatever view we may entertain as to the soundness of the reasons on which the rule was originally established," a Vermont judge observed in 1860 , "it is now so firmly supported by authority that it would not be wise to overturn it."118

\section{The "Exceptions" to the Fellow Servant Rule}

The broad Fellow Servant doctrine was not universally accepted. While those jurisdictions that followed the rule recognized that the principle was a "comprehensive doctrine, and applies to all agents engaged in the business of the principal,"120 several jursidictions so severely qualified the rule that its effect in exempting an employer from liability was virtually nullified. The technique by which they did so was to create exceptions which came close to swallowing the rule. These "exceptions," which came in a variety of forms, gave the late nineteenth-century rule its characteristic incoherence which contrasted so sharply with the clarity of Shaw's rule. No account of the development of the rule, therefore, would be complete without an examination of the "exceptions."

Those scholars who explain the rule as a response to economic needs have a ready corollary to explain the growth of the exceptions. The Fellow Servant rule served its purpose of subsidizing the growth of railroads during the great years of railroad expansion prior to 1860 . By "the end of the century," Friedman and Ladinsky observe, "the fellowservant rule had lost much of its reason for existence: it was no longer an efficient cost-allocating doctrine," and therefore the rule was progressively weakened by the development of exceptions. ${ }^{121}$

116 Mitchell v. Pennsylvania R.R, 1 AM. L. Reg. 717, 718 (1853).

117 Moseley v. Chamberlain, 18 Wis. 700,705 (1861).

118 O'Connell v. Baltimore \& O.R.R., 20 Md. 212, 219 (1863).

11 Hard v. Vermont \& Can. R.R., 32 Vt. 473, 478 (1860). dissenting).

120 Little Miami R.R. v. Stevens, 20 Ohio 415, 447 (1851) (Spalding, J.,

121 Friedman \& Ladinsky, supra note 5, at 62, 59. As F. Pollock described the process, "[t]here are some authorities which are followed and developed in the spirit, which become the starting-point of new chapters of the law; there are others that are followed only in the letter, and become slowly but surely choked and crippled by excep- 
Yet such an explanation does not account for the process by which the exceptions in fact developed. The most important exceptions, and their justifications, developed contemporaneously with the broad rule itself. They were an alternative to Shaw's Fellow Servant rule, rather than an outgrowth of it. The most important exceptions developed in early cases of first impression, when several courts rejected the Priestley v. Fowler ${ }^{122}$ and Farwell v. Boston $\mathcal{E}^{2}$ Worcester Rail Road ${ }^{123}$ rationales and held employers liable. These courts created "exceptions" which happened to coincide exactly with the facts of the cases before them.

Several questions are raised by the use of this technique. If the rationale for accepting the rule was to foster the growth of nascent railroads, why was the "acceptance" of the rule so grudging and qualified? On the other hand, if the judicial aim was to reject the rule, why was this not done outright? To address these questions, this Comment examines the development of the most important exceptions to the rule, in treatises and in the cases from several jurisdictions. It concludes that "exceptions" were an acceptable way of expressing dissent while preserving a veneer of judicial consistency. It notes, however, that the long range consequence of decision by "exception" was a rule of tort law that was as confused as it was cruel.

\section{A. The Treatises: Roots of the Exceptions}

The theoretical roots of one of the most important exceptions, that which imposed liability upon a master when the negligent servant worked in a "different department" from the victim, may be traced to 1844 , only two years after the Farwell opinion. In that year, Joseph Story published the second edition of his Commentaries on the Law of Agency. ${ }^{124}$

The first edition was published in 1839, two years after Priestley. Section 452 contained Story's restatement of the principle of respondeat. Relying on established master/servant law, ${ }^{125}$ Story affirmed the principle of respondeat and followed his discussion with copious illustrations indicating the extent of the doctrine's reach. ${ }^{128}$

tions." F. Pollock, The Law of Fraud Misrepresentation and Mistake in BRITISH INDIA 53-54 (1894), cited in R. Pound, supra note 13, at 135 (emphasis added).

122150 Eng. Rep. 1030 (1837).

12345 Mass. (4 Met.) 49 (1842).

124 J. STORY, CoMmentaries on THE LAW of Agency (2d ed. 1844) [hereinafter cited as STORY II].

125 See supra text accompanying notes 22-31.

128 J. StORY, Commentaries ON THE LAw OF Agency $\S$ 452-453 (1839) 
When Story's second "revised, corrected, and enlarged" edition was printed in 1844, he added a large subsection, 453(d), to consider the question whether respondeat applied "to cases of different agents, employed by the same principal, where one, by his misfeasance, or negligence . . . does an injury to the other." ${ }^{127} \mathrm{He}$ noted that the issue had recently "become a subject of judicial examination," and his discussion of Priestley and Farwell indicates that he doubted the correctness of their new rule. ${ }^{128}$ The way in which he framed his discussion certainly had the effect of narrowing the rule's scope. He began by dividing into two classes the situations to which the rule might be applied: the first, in which fellow servants were employed "in the same business or employments," and the second, in which they were engaged in different departments. Story treated both Priestley and Farwell as applying to the first category only. Neither case, he believed, covered the situation where a common employer engaged two agents in different parts of his business. In such a situation, Shaw's rationale of providing incentives for employees to watch for the negligence of their colleagues could not apply; therefore, the expansive respondeat principle would still cover the case. ${ }^{129}$ In Farwell, however, Shaw had considered and rejected any such idea that his general rule was inapplicable to employees working in "different departments."130

Story's categorization and confinement of the Fellow Servant rule exemplifies the role played by nineteenth-century legal treatise writers. Story, former Supreme Court Justice and first Dane Professor at Harvard, was undoubtedly the leading treatise writer of his era. ${ }^{131} \mathrm{He}$ shared a conception of his function, however, with less exalted colleagues. Their job was to harmonize and systematize conflicting decisions on increasingly technical legal subjects. This role led them, as it

[hereinafter cited as STORY I]. Story criticized a much-quoted section of Blackstone on respondeat as being too restrictive of the maxim. Id. $\S 453$, at 466 n.2.

127 STORY II, supra note $124, \S 453$ (d).

128 In discussing Priestley, Story clearly distanced himself from Abinger's description of the consequences of a contrary decision: "Any other doctrine (it is said) would lead to mischievous consequences." STORY II, supra note $105, \S .453$ (d), at 565 . He characterized Shaw's Farwell opinion as "elaborate" rather than "sound" or "wellreasoned." Id. $\S 453(\mathrm{e})$, at 567 n.1.

${ }_{129} I d . \S 453(\mathrm{~d})$-(f). He proceeded to give a number of examples of the "intrinsic difficulties and inconveniences in pressing the doctrine . . . to such a large extent." Id. $\S 453(\mathfrak{f})$, at 571 . One of his hypothetical examples involved a carpenter, employed to build a house for a coach-owner, who was injured while travelling in the coach toward his workplace. Id. A very similar factual situation faced the Indiana Supreme Court in Gillenwater v. Madison \& I.R.R., 5 Ind. 339 (1854). See infra text accompanying notes 191-200.

13045 Mass. (4 Met.) at 60 .

131 L. FRIEDman, supra note 5, at 288-89. 
did Story, to go beyond the decided cases and to "caution" or "on proper occasions, by remarks, notes and comments, to examine and explain ... and sometimes to show the law is not, as it has been in some decisions stated to be."132

Story's treatment of the Fellow Servant rule set the pattern for subsequent and more specialized treatises, such as Redfield and Pierce on railways, and Angell on common carriers. ${ }^{133}$ In place of Shaw's broad rule, they (like Story) presented a more limited rule followed by a growing number of "exceptions," or situations in which, for one reason or another, the rule did not apply. ${ }^{134}$

These writers wielded considerable authority. In theory, of course, even the best treatises were not supposed to have "the character of an authority, which can properly belong only to adjudged cases."135 In practice, however, lawyers depended heavily upon them. They figured prominently in arguments of counsel in Fellow Servant cases. ${ }^{136}$ In several jurisdictions, in fact, the rule and its limitation were adopted largely on the authority of Story, Redfield, or Angell. ${ }^{137}$ The doubts and qualifications of the treatise writers, however, created weighty authority on the other side. If the treatises very early put a qualified stamp of approval on the "general rule," they also approved and legitimized the idea that the "rule" must be subject to many "exceptions."138

1321 N. Dane supra note 22, at vii, iv. See, e.g., J. Angeld, A TrEatise on the Law of Carriers of Goods and Passengers by Land and by Water v (1849):

The objection of the author has been to consider the law on the subject proposed as it now is, and at the same time to point out such discrepancies as he has discovered to have occurred, in the course of the gradual adaptation, by judicial tribunals, of leading principles to the vastly multiplied exigencies of commerce and of society.

The function that treatise writers were performing in the early nineteenth century is that which White ascribed to later legal scholars; that is, they "extracted principles from a variety of judicial opinions. Once extracted, these principles were articulated as working guides to an area of law." G. WHITE, supra note 1, at 39. 132.

${ }^{133}$ I. REDFIELD, supra note 61; E. PIERCE, supra note 61; J. ANGell, supra note

${ }^{134}$ Pierce, by 1857, stated the general rule in 8 pages, and the exceptions in 15 . E. PIERCE, supra note 61, at 286-310.

${ }^{185}$ Chittenden, Preface to T. Reeve, supra note 22, at iii.

136 See, e.g., Little Miami R.R. v. Stevens, 20 Ohio 415, $422-23$ (1851) (defendant in error's argument); see also Walter v. Bolling, 22 Ala. 294, 297 (1853) (defendant in error's argument); Scudder v. Woodbridge, 1 Ga. 195 (1846) (defendant in error's argument).

137 See, e.g., Scudder v. Woodbridge, 1 Ga. 195, 198 (1846) (the general rule "may be correct" as it is "distinctly laid down in Story on Agency"); Haynes v. East Tenn. \& Ga. R.R., 43 Tenn. (3 Cold.) 222, 224 (1866) (citing I. Redfield, supra note 61).

${ }^{138}$ See, e.g., I. REDFIELD, supra note 61, at 426 n.9. After citing at length to the Scots authorities, which heavily criticized the policy justifications of the rule, he added 


\section{B. The Effect of the Legal Information Explosion}

The phenomemon of a broad general rule adopted simultaneously with numerous exceptions can be traced in part to the legal information explosion in the early nineteenth century. In sharp contrast to the paucity and unreliability of reported cases in the eighteenth century, by 1830 every state had an official reporter system, and lawyers in every jurisdiction struggled with a flood of case authority for any particular legal proposition. ${ }^{139}$ As impressive as the reports were the proliferating new legal periodicals. ${ }^{140} \mathrm{~A}$ major function of these journals was to place recent decisions before lawyers even faster than the reports could. ${ }^{141}$

These new sources gave lawyers and judges a wealth of data from which to glean the "correct" result in any case, but no corresponding theory which would help in choosing between the authorities because, in theory, there should have been no conflict. Precise theories of precedent and stare decisis are creatures of the late nineteenth century. ${ }^{\mathbf{1 4 2}}$ Before then, it was not clear when one court was bound to follow the decision of another; it was even less clear when a decision of a "foreign" jurisdiction was so authoritative as to be "persuasive," if not binding. ${ }^{143}$

he "could not forbear to state, that we have always had similar difficulties . . . in regard to the justice, or policy of the rule" and noted that he thought there ought to be some "discretion and reserve ... in the application of the rule." Redfield was cited by those judges who wished to narrow the rule. See, e.g., Indianapolis \& C.R.R. v. Love, 10 Ind. 554, 557 (1858). See generally Cleveland, C. \& C.R.R. v. Keary, 3 Ohio St. 201, 228 (1854) (Warden, J., dissenting).

139 See, e.g., Story, supra note 55, at 213 (Story pointed with pride to the "outpouring of reports, and their high quality." "The danger, indeed, seems to be not that we shall hereafter want able reports, but that we shall be overwhelmed by their number and variety."); see also N. DANE, supra note 22, at iv; T. REEVE, supra note 22, at iv; American Reports and Reporters, 22 AM. JuRIST 108 (1840).

160 For example, this Review was founded as the American Law Register in 1852.

141 Bloomfield, Law and Politics: The Self-Image of the American Bar, 18301860, 12 AM. J. Legal Hist. 306, 309-10 (1968).

162 R. Cross, supra note 35, at 20; see also Simpson, supra note 104. Simpson notes that even today the "rules governing the use of authorities in legal argument" are all "a very theological world, with mysteries similar to those which surround the doctrine of papal infallibility. ... We all know that the practice of the courts is not at all consistent in these matters. . . . All is reminiscent of the smile on the face of the Cheshire cat." For courts attempting to determine the "authoritarian pecking order ... [t] ]here are no rules to deal with conundrums of this sort." Id. at 87; see also K. LLEWellyn, The Common Law Tradition: Deciding Appeals 77-91 (1960) (Llewellyn describes 64 possible ways to use precedent from "following" to "avoidance.").

${ }^{143}$ The distinction between precedent that is binding and that which is merely persuasive is confusing even now. See C.K. Allen, LAW IN THE MAKING 260-61 (6th ed. 1958); Simpson, supra note 104, at 76; see also Lewis, Precedent, 47 L. REv. Q. 411,421 (1931). It was more so in the 18 th and 19th centuries when precise rules had yet to be formulated. On 18th century America, see Smith, New Light on the Doctrine of Judicial Precedent in Early America: 1607-1776, in LEgal. Thought IN THE 
In the early nineteenth century, attempts to order the conflicting decisions which did in fact emerge from "twenty-five sovereignties," as Dane noted, presented serious problems. ${ }^{144}$ Courts responded to the need for stability and harmony, ${ }^{145}$ the mass of conflicting case law, and the absence of precise rules for ordering authorities by developing ad hoc rules for judging the persuasive force of any particular "foreign" case. ${ }^{148}$

The new sources of information accelerated preexisting trends. Farwell, as noted before, was precisely the type of opinion that would readily be followed. ${ }^{\mathbf{1 4 7}}$ As cases qualifying or rejecting Shaw's rule began to appear, the new legal information system showed that the myth of common law harmony was increasingly intellectually untenable. By widely disseminating the "exception" cases, the reporters and journals gave impetus to those judges disposed not to follow Shaw's broad formulation of the rule.

\section{Ohio: The Superior Servant Exception}

Ohio's acceptance of the Fellow Servant rule was so qualified, and the exception it created so broad, that it was sometimes cited as a jurisdiction which had rejected the rule outright. ${ }^{148}$ In fact, in the first such case to come before the Ohio Supreme Court, Little Miami Railroad $v$. Stevens ${ }^{148}$ the divided court did reject the rule, the only early case to do so. ${ }^{150}$ The three opinions in the case present, in microcosm, the range of judicial options open to courts in the 1850's when faced for the first

United States Under Contemporary Pressures (J. Hazard \& W. Wagner eds. 1970).

${ }_{144}$ See 1 N. DANe, supra note 22, at xiv-xv.

145 See, e.g., the admonition of Shaw himself, that although it was often immaterial which way a rule was fixed, it is of the greatest importance, that it be steadily adhered to in order to "afford security." Shaw, supra note 111.

148 The Fellow Servant cases demonstrate the way the system worked. After authoritative English cases, often cited first, decisions of respected state courts (like those of Massachusetts and New York) came next, occasionally yielding to citations of authoritative treatise writers like Joseph Story and Isaac Redfield. Next came lists of citations from neighboring states, in no particular order. This ad hoc, unsystematic approach to the problem of harmonizing conflicting state authority led, in part, to the codification movement. See Story, supra note 55, at 214, 237. For a contemporary condemnation of this random citation pattern, see The Citing of Authorities, 8 AM. JURIST 111,117 (1832).

147 See supra notes 109-14 and accompanying text.

148 Hard v. Vermont \& Can. R.R., 32 Vt. 473, 479 (1860); I. RedFIELD, supra note 61 , at $425 \&$ n.6.

14820 Ohio 415 (1851).

180 After Little Miami the Ohio Supreme Court implicitly, then explicitly, adopted the Fellow Servant rule with the superior servant exception. See infra notes 177-88 and accompanying text. 
time with a Fellow Servant question.

John Stevens was driving an eastbound train for the defendant railroad company when the train collided with a westbound train also owned by the Little Miami. As stated in the declaration, the plaintiff was "violently crushed" and was "greatly scalded, bruised, lacerated, hurt and wounded, and in consequence thereof became, and was sick, sore, lame, and disordered."151 The collision occurred because of a change in schedule of which the plaintiff was not informed but of which the conductor-the "commanding officer" of the train ${ }^{152}$-apparently was. ${ }^{153}$ The jury returned a verdict for the plaintiff in the amount of $\$ 3700.154$

The lawyers' arguments on appeal gave little hint of the decision that was to come. The defendant, predictably, relied on Story, Priestley, and Farwell (in that order) for the proposition that the broad Fellow Servant rule was "well settled."15s Rather than arguing against the rule, however, the plaintiff's counsel maintained that Stevens' case ought to constitute an exception. ${ }^{158}$

The majority opinion by Judge Caldwell was a model of the instrumental judicial style. Caldwell based his opinion not on precedent, but on reason and policy. He began with the general rule, "founded in reason," that a principal must be held responsible for the consequences of any power he sets "in motion for his own benefit." was supported by policy, he observed, for "it is necessary as a preventive of mischief, and a protection to [the] community."158 Caldwell then confronted directly the central Priestley and Farwell legal argument that an employee's implied employment contract and his level of wages encompassed his assumption of risk of a co-worker's negligence. "If the party does contract in reference to the perils incident to the business,"

15120 Ohio at 417.

182 Id. at 429.

153 The majority cited the testimony of an assistant in the engineering department who stated that a time card showing the schedule change was given to the conductor, but that "he kn[ew] of no card being delivered to Stevens." Id. at 430. In his concurring opinion, Chief Judge Hitchcock stated that it was "doubtful" that either Stevens or the conductor had been notified of the change, and he attributed the collision to the negligence of the railroad superintendent whose duty it was to notify the engineer and conductor of schedule changes. $I d$. at 437.

184 Id. at 417.

${ }^{165} I d$. at 422 ("It is well settled that the master is not liable for injuries sustained by one workman or servant by the careless or negligent or unskillful act of another workman or servant." (emphasis in original)).

${ }^{158}$ Id. at 425 ("But we claim that this case at bar is within the exception admitted by the very authorities cited against us.").

187 Id. at 431.

${ }^{168} \mathrm{Id}$. at 432. 
Caldwell noted, "he will only be presumed to contract in reference to such as necessarily attend it when conducted with ordinary care and prudence."188 "The employer has paid him no money for the right to break his legs," he wrote scathingly, "or, as in this case, to empty on him the contents of a boiler of scalding water."160

Caldwell also rejected the policy argument employed in Priestley and Farwell, that the adoption of the Fellow Servant rule would promote safety in the workplace by giving employees an incentive to be watchful of their co-workers' misconduct and carelessness. ${ }^{161}$ Caldwell responded to this argument by stating that "we do not think it likely that persons would be careless of their lives and persons or property" solely because they had a cause of action against the employer for provable injuries. ${ }^{162}$ "If men are influenced by such remote considerations to be careless of what they are likely to be most careful about," he concluded caustically, "it has never come under our observation."163

Having discussed and disposed of Priestley and Farwell, Caldwell declared himself not to be bound by them. Although he could easily distinguish the case before him on its facts, he did not deign to do so. "So far as those cases decide that a recovery cannot be had in a case like the one now before the Court," he held, "we think they are contrary to the general principles of law and justice, and we cannot follow them as precedents."164

Caldwell's bold style was mirrored by an equally strong dissent by Judge Spalding. Spalding, however, looked to the past for his judicial model; his opinion would not have appeared out of place in any eighteenth-century report. ${ }^{105} \mathrm{He}$ carefully canvassed the precedents and con-

$169 I d$

$160 \mathrm{Id}$

161 Farwell, 45 Mass. (4 Met.) at 59 ("By these means, the safety of each will be much more effectually secured, than could be done by a resort to the common employer for indemnity in case of loss by the negligence of each other."); see Priestley, 150 Eng. Rep. at 1033 (preventing the co-worker from recovering against the employer is "a much better security against any injury the servant may sustain by the negligence of others engaged under the same master than any recourse against his master for damages could possibly afford").

16220 Ohio at 434.

$163 I d$.

164 Id. at 435. Caldwell's opinion, in its rejection of precedent and its dependence on reason and social policy, precisely fits the Horwitz model. See supra text accompanying notes 8-10 and notes 50-51. See generally M. HorwITz, supra note 1, at 22-26.

165 Although Judge Spalding's opinion indicated a strong adherence to the traditional notion that courts are bound by precedent, cf. supra notes 102-06 and accompanying text, it should be noted that his rationale at least acknowledged public policy considerations which Horwitz claims guided judges in the mid-nineteenth century. Spalding stated, "The law thus settled is founded in wisdom, and on principles of public policy, adapted to our condition, and should not, therefore, be changed." 20 
cluded that "[ $\mathrm{t}] \mathrm{h}$ he solemn adjudications of Courts of recognized authority should be followed," as "[t]here is nothing to distinguish this State from others."168 $\mathrm{He}$ direly cited Latin maxims to the effect that "even when the reason of a rule cannot well be discerned, 'the wisdom of the rule has in the end appeared, from the inconveniences that have followed the innovation." "167 The irony, of course, is that the American rule which Spalding wished to protect against innovation was barely a decade old.

The third opinion in Little Miami was that of Chief Judge Peter Hitchcock, one of the great judges of his time. ${ }^{168}$ Hitchcock, far from following Caldwell's bold line, concurred in the judgment only. He was deeply disturbed by Caldwell's approach, for, he noted, "[i]f this case were, in its principal features," like Farwell or Priestley, "I should hesitate long before I would consent to disregard those decisions."169 "They were," he observed, "decisions made by highly respectable tribunals, and by men whose opinions are entitled to the highest considerations."170 Happily for Stevens, however, Hitchcock discerned a distinction that enabled him to decide for the plaintiff "without conflicting at all with the authorities."171

Hitchcock began by finding that the accident was not caused by either the engineer or conductor, but rather by "the superintendent of the road." $172 \mathrm{He}$ then stated that employees of the company "engaged in making or repairing their road, or in running their cars," such as the

Ohio at 440 (emphasis added). Horwitz notes that one of the first steps taken by eighteenth and nineteenth century judges was to recognize that English precedent was based on conditions different from those existing in American society. "[T]o follow "arbitrary rules' or 'arbitrary decisions' without understanding that they 'arose out of [a different] state of society' would be 'certainly contrary to the principles of our government and the spirit of our laws.' " M. HoRwITz, supra note 1, at 25 (quoting from a 1793 dissertation by Vermont Chief Justice Nathaniel Chipman).

16820 Ohio at 449.

${ }^{167}$ Id. Spalding relied upon "jus dicere et non jus dare" ["to say what the law is, not to make it"] and "omnis innovatis [sic] plus novitate perturbat, quam utilitate prodest" ["every innovation occasions more harm by its novelty than benefit by its utility"].

${ }_{168}$ Peter Hitchcock was one of the great early nineteenth century judges. See L. Friedman, supra note 5, at 118. Educated at Yale, he moved to Ohio in 1806. After a full political career in the Ohio legislature and the United States Congress, he was appointed a judge of the Ohio Supreme Court in 1819, and Chief Judge in 1831. He "retired" in 1851, at age 70, when Ohio's Supreme Court became an elective body. 9 Dictionary of AMERICAN BIOGRAPHY 77 (1932). As the Dictionary of American Biography described his judicial style, "[h]e had little reverence for rule and precedents established under unlike conditions . . .." Id.

189 Ohio at 436.

170 Id.

171 Id.

172 Id. at 437; see supra note 153. 
plaintiff, are truly "servants" of the company. ${ }^{173}$ The superintendent, however, is an "agent" or "proper representative of the Company" and is thus not an employee or servant. ${ }^{174}$ Hitchcock concluded that the plaintiff should therefore recover because his "injury resulted from the negligence of the Company itself, or of an agent whose duty it was to give the notice" of the schedule change to the engineer and conductor, and not from the negligence of a fellow servant or employee. ${ }^{175}$

Hitchcock's opinion is significant because it is an example of the preferred judicial response to an authoritative line of cases which, if followed, would yield an inappropriate result. Rather than reject the broad Fellow Servant rule, as Caldwell had done, Hitchcock sought to exempt the particular case before him from its force. Courts that resisted the rule tended to do so by following Hitchcock's rather than Caldwell's approach. ${ }^{178}$

Hitchcock's strategy of distinguishing the case before him from the strictures of the broad Fellow Servant rule was in fact adopted by the Ohio Supreme Gourt in the next Fellow Servant case to come before it. ${ }^{177}$ In Cleveland, Columbus $\mathcal{E}$ Cincinnati Railroad v. Keary, ${ }^{178}$ the plaintiff, a brakesman employed by the defendant, was "very seriously and permanently injured" by a collision between a locomotive and train owned by the defendant. ${ }^{178}$ The evidence at trial indicated that the collision was caused by the negligence of either the conductor or the superintendent, and the jury returned a verdict for the plaintiff in the amount of $\$ 6,050 .{ }^{180}$ On appeal the railroad's counsel strongly urged the reconsideration of Little Miami, ${ }^{181}$ but the majority of the supreme court, speaking through newly elected Judge Ranney, reaffirmed that

12320 Ohio at 438 (emphasis deleted).

134 Id.

${ }^{175} \mathrm{Id}$.

176 See generally infra notes 205-24 and accompanying text.

177 In 1851, a new Ohio constitution was adopted providing for popular election of judges. The court which decided Cleveland, C. \& C.R.R. v. Keary, 3 Ohio St. 201 (1854), the next Fellow Servant case to reach Ohio's Supreme Court, consisted of elected judges and was without Hitchcock's services. Whatever effect the popular election of judges was intended to have, it resulted in an Ohio court which narrowed an employer's liability for employee accidents.

1783 Ohio St. 201 (1854).

178 Id. at 202.

180 Id. at 202-03.

182 The court stated that the railroad's counsel questioned the "correctness" of Little Miami because "it was made by a divided court, and is claimed to be in conflict with several cases decided elsewhere, by courts of acknowledged learning and ability." Id. at 204. According to eighteenth-century dogma opinions by unanimous courts and by well-respected tribunals were accorded more precedential weight because those courts were more likely to have "discovered" the law correctly. See supra notes 105-06 and accompanying text. 
decision with "unqualified approval."182

Despite this strong affirmation of Little Miami, the Keary court nonetheless treated Priestley and Farwell in a manner far different than had the Little Miami majority. Caldwell's majority opinion had ridiculed those precedents and rejected the Fellow Servant rule; the Keary court, however, proceeded less boldly. Judge Ranney began by stating that he entertained "the highest respect" for the Priestley and Farwell courts, and would "hesitate long before [he] differed from them."183 $\mathrm{He}$ instead distinguished those precedents from the case before him: "While we cannot approve all that is said in [Priestley and Farwell, neither] of them has determined the question now before us." "N84 Neither of these precedents, he continued, held that the employer "is not liable for the negligent and careless conduct of him to whom he delegates the power of control and command over" the injured employee. ${ }^{185}$ Keary's result, therefore, far from affirming Little Miami's rejection of the Fellow Servant rule, instead created created a "superior servant" exception. The creation of the exception implied the acceptance of the general rule itself. $^{186}$

Ohio explicitly adopted the Fellow Servant rule in Whaalen $v$. Mad River \& Lake Erie Railroad, ${ }^{\mathbf{1 8 7}}$ the next Fellow Servant case to reach Ohio's Supreme Court. In Whaalen, the injured employee was not a subordinate, but rather was employed in a department of the railroad separate from that of the negligent employee. The rationale of Little Miami and Keary covered this situation as well: if an employee could not assume risks of a superior's negligence because he was unaware of or had no means of avoiding the danger, he certainly could not do so when he was not even in communication with the negligent party. Yet, in a highly technical opinion, the court ignored that rationale and held that Ohio's "superior servant" exception applied only to superiors who negligently caused injury to subordinate employees. By 1858,

1823 Ohio St. at 204.

183 Id. at 212.

184 Id.

185 Id. at 217. of Keary.

188 Justice Warden, who concurred in the judgment, clearly saw the implications

[T] he ground on which I would place the right of the plaintiff below, is so much broader than that taken by the majority of the court, that, in view of the construction which will be given to their ruling, and what appear to me its consequences, I feel bound to state my qualified dissent ... .

Id. at 219. The shift in Keary was so subtle, and the policy denunciation of the rule so strong, that Keary continued to be cited as a case contrary to the rule. See, e.g., I. REDFIELD, supra note 61 , at 388 n.6.

1878 Ohio St. 249 (1858). 
therefore, in the interests of judicial harmony, ${ }^{188}$ the Ohio court had turned an expansive, policy-based rejection of the Fellow Servant rule into a narrowly defined "superior servant" exception.

Even at its narrowest, however, the exception represented a significant departure from Farwell's broad statement of the rule. Given the hierarchical nature of railroad organization, ${ }^{189}$ the superior servant exception imposed liability on the railroad in a significant number of cases. The fact that the limitation on the rule was couched in terms of an exception, therefore, should not obscure the fact that its development represented a considerable expression of judicial dissent from the rule.

\section{Indiana: The Separate Department Exception}

Indiana's qualification of the Fellow Servant rule became the "separate department" exception. In 1860, an Iowa court, when first considering the Fellow Servant rule, criticized Indiana for its "innovation of an established rule."180 In fact, Indiana's "innovation" arose in its case of first impression, Gillenwater $v$. The Madison $\mathcal{E}$ Indianapolis Railroad. ${ }^{\text {ig1 }}$

In Gillenwater, the plaintiff was a carpenter employed by the railroad to build a bridge. ${ }^{192}$ As he rode the train to his workplace, the negligence of the engineer and conductor caused a derailment of the train. According to the plaintiff's declaration, the mishap resulted in the fracturing of his right hand, "so as forever to disable him from pursuing his business of housecarpenter." "18s In their answer, the defendants argued that the negligent servants were "competent and skilful," and that as a fellow servant of the engineer and conductor, the plaintiff should not recover. ${ }^{104}$ The trial court sustained a general demurrer in favor of the railroad.

In reviewing this decision, Justice Stuart, speaking for a unanimous supreme court, began by discussing critically the decisions adopting the Fellow Servant rule. Stuart was particularly dubious of Far-

${ }^{288}$ The court's concern to narrow the gap between Ohio's rule and the current of judicial opinion is a major theme of the opinion.

${ }^{180}$ The stratification was explicit: superintendent over trackmen; conductor over engineer; engineer over brakemen and firemen. See S. SALSBURY, supra note 80, at 112-13.

190 Sullivan v. Mississippi \& Mo. R.R., 11 Iowa 421, 425 (1860).

1815 Ind. 339 (1854).

192 The quasi-employee status of the plaintiff lent credence to the court's attempt to distinguish the case from the authorities, in that he could have been viewed as a passenger, and thus covered by respondeat.

1935 Ind. at $340-41$.

194 Id. at 341. 
well, noting that Shaw used very "cautious concluding language" suitable "in relation to some legal heresy" which "strongly implie[d] a suspicion of the correctness of the principle sought to be established."195

Having expressed his reservations regarding the leading American Fellow Servant case, Stuart had two courses open to him. He could reject the rule, or he could follow Hitchcock's lead to distinguish the case on its facts. The latter route was too tempting. "So clearly is the case at bar distinguished from the Farwell case," he observed, "that we are not called upon either to approve or dissent from the doctrine there held."198 In Farwell, as in Priestley, the employees were "intimately associated in the business," 197 whereas in Gillenwater, the plaintiff was in a "remote" department if, indeed, he was an employee at all. $\mathrm{He}$ was, in any event, unconnected with the "careless management" which had injured him. ${ }^{198}$ Farwell, the court held, must be strictly limited to those situations to which its implied contract and assumption of risk rationales applied, namely, those in which the servant was aware of the possibility of a colleague's negligence and could act to avert an injury. To extend the rule to employees of different departments, he observed, would be "vicious and absurd."189 Thus was born Indiana's "separate department" exception. ${ }^{200}$

The court confirmed its rule in Fitzpatrick v. New Albany \& Salem Railroad, ${ }^{201}$ the next Fellow Servant case to come before it. Here,

${ }^{195}$ Id . at 346-47. Shaw's "cautious concluding language" was, in reality, an attempt by Shaw to dot his "i's" on the outer limits of his rule. Having encompassed virtually all master/servant relations under the broad language of his rule, he added "a caution against any hasty conclusion as to the application of this rule to a case not fully within the same principle." He then drew his line at a master's duty to furnish an employee with nondefective equipment (burden of proof on the plaintiff). 45 Mass. (4 Met.) at 62.

1985 Ind. at 344.

187 Id. at 343.

${ }^{198} I d$. at 345. Gillenwater's status-employee or independent contractor-was not made clear in the opinion. The court, however, treated him as an employee which in turn bound the court to deal with his case as a Fellow Servant problem. In the next Fellow Servant case, the court's discussion of the Gillenwater precedent indicated it believed the plaintiff there to have been an independent contractor, but it believed the Gillenwater 'separate department' exception was fully applicable to employees nevertheless. See infra text accompanying notes 201-03.

1995 Ind. at 345. Stuart concluded that even Farwell had "clearly admitted that where the duties do in fact belong to different departments, a distinction should be made." Id. This was a monumental misreading of Farwell. Shaw in fact used the language cited by Stuart to oppose any such "supposed distinction, on which it would be extremely difficult to establish a practical rule." 45 Mass. (4 Met.) at 60 . Pierce attempted, without much success, to harmonize the two cases. See E. PIERcE, supra note 61 , at 300 n.1.

200 The "separate department" exception was a popular one. See, e.g., Hough v. Railway Co., 100 U.S. 214, 217 (1879).

${ }^{201} 7$ Ind. 436 (1856). 
the injured party was definitely an employee, a track repairman, rather than an independent contractor, who was injured by an engineer's negligence. The court recognized that the case could thus be distinguished from Gillenwater on its facts, but it declined to do so. The court rejected Farwell's rationale by holding that an employee "can not be presumed to have contracted in reference to injuries inflicted on him by negligence." ${ }^{202}$ The principle of Gillenwater, the court therefore concluded, covered the case of the track repairman, as well as the railroad carpenter. ${ }^{203}$

The development of Indiana's rule was another example of the effort to express judicial dissent within the constraints imposed by legal norms of harmony and consistency. The result was a Fellow Servant rule that lacked any legal coherence at all. The "separate department" exception itself was a masterpiece of confusion, as Shaw had predicted it would be. ${ }^{204}$

\section{E. Jurisprudence by Exception}

Developments in Ohio and Indiana were not unique. As Fellow Servant cases came before other jurisdictions, new "exceptions" were created, often in cases of first impression. The variety of these exceptions was limited only by the varying factual contexts in which negligent employees could kill or maim their co-workers. In several southern states, therefore, a "slave" exception developed. Courts rationalized the exception by observing that slaves were neither free to leave their employment nor to report a white co-worker's negligence and thereby avoid its consequences. ${ }^{205}$ Similarly, when accidents occurred between

202 Id. at 439.

${ }^{203} \mathrm{Id}$. at 440 ("There is really no difference in principle, between this and the Gillenwater case, and we are inclined to adhere to that decision.").

${ }_{204}$ See 45 Mass. (4 Met.) at 60 . Pierce noted in 1857, "[i]t may not be easy to state the principle which will distinguish in advance one department of service from another, so that the employees in one are not to be considered the co-servants of persons employed in another; but the distinction itself cannot well be denied." E. PIERCE, supra note 61 , at 305 .

${ }^{205}$ See, e.g., Scudder v. Woodbridge, 1 Ga. 195, 198 (1846), where Justice Lumpkin noted that the "general doctrine . . . may be correct," but "interest to the owner, and humanity to the slave, forbid its application to any other than free white agents." In the next Fellow Servant case to come before the Georgia high court, an action by a father against the railroad for an injury to his son, the court cited Scudder as having established the rule in Georgia. See Shields v. Yonge, $15 \mathrm{Ga} .349,358$ (1854). Compare Ponton v. Wilmington \& W.R.R., 51 N.C. (6 Jones) 245, 247 (1858), in which Thomas Ruffin, another of the great 19th century judges, found that, even if he disagreed with the Fellow Servant rule, "it would not have been possible to resist the authority of such an array of consistent decisions of able courts" and held that no distinction was to be made in the case of a slave. 
employees of a similar rank, some courts developed a "competent servant" exception, reasoning that no implied employment contract could relieve a master of his obligation to hire competent employees, nor could an employee assume the risk of a co-worker's incompetence. ${ }^{208}$ When accidents occurred because of defective equipment, some courts found a "warranty of safe equipment" exception, for it was the master's duty to guarantee the safety of the equipment and the employees could not be expected to assume risks of which they were not aware. $^{207}$ When, in 1879 , the Supreme Court finally adopted the Fellow Servant rule, it did so in a very narrow way, listing no fewer than four "well defined exceptions" resting "upon principles of justice, expediency, and public policy" by which the rule must be qualified. ${ }^{203}$

The combined effect of these exceptions, which were adopted variously by the different jurisdictions, was to rob the rule of much of its economic effect since many railroad accidents were covered by one exception or another. Moreover, the opinions of the courts adopting the exceptions demonstrate serious dissatisfaction with the policies and premises of the Fellow Servant rule. The question then becomes, why did they consistently carve out exceptions which ill served railroad interests, and which made no legal sense?

One reason for the pattern described above is intellectual. The system of precedent not only preserves the legitimacy of judicial decisionmaking, but it reinforces the judge's own sense of the correctness of his views. No person, even a judge, prefers to stand alone and exposed. The effect of this phenomenon on the Fellow Servant rule was graphically demonstrated in Wisconsin, which, like Ohio, at first, rejected the rule. In a lengthy opinion in Chamberlain $v$. Milwaukee $\&^{2}$ Mississippi Railroad, ${ }^{200}$ Justice Paine criticized the entire range of Fellow Servant cases, and the policies underlying them. He recognized that a great ma-

208 See Walker v. Bolling, 22 Ala. 294 (1853); Bassett v. Norwich \& W.R.R., 19 Monthly Law ReP. (n.s. No. 9) 551, 554 (Super. Ct. Conn. 1857); Keegan v. Western R.R., 8 N.Y. 175, 180 (1853); Noyes v. Smith, 28 Vt. 59, 63 (1856). It should be noted that in Farwell Shaw reserved ruling on the question whether the Fellow Servant rule applied in cases in which the employer failed to hire "a person of suitable skill and experience." 45 Mass. (4 Met.) at 62.

${ }_{207}$ See Harrison v. Cent. R.R, 31 N.J.L. 293 (1865); Noyes v. Smith, 28 Vt. 59, 63 (1856). It should be noted that in Farwell Shaw explicitly left open the question "[w]hether, for instance, the employer would be responsible to an engineer for a loss arising from a defective or ill-constructed steam engine." 45 Mass. (4 Met.) at 62 .

${ }^{208}$ Hough v. Railway Co. 100 U.S. 213, 216-17 (1879). The exceptions were: master's duty of due care; to provide safe equipment; to provide competent colleagues, and the "separate department" exception. For previous hesitations, see Railroad Co. v. Fort, 84 U.S. (17 Wall.) 553 (1873); Philadelphia \& R.R.R. v. Derby, 55 U.S. (14 How.) 467 (1852).

20011 Wis. 238 (1860). 
jority of them had decided that an employer should not be held liable. But he conceived that a court must not only "count but ... weigh the cases, and by this test the majority do not always rule." $210 \mathrm{He}$ recognized that both Ohio and Indiana had couched their opposition to the rule in terms of exceptions, a tactic he believed was suggested "out of deference to authorities, from which they did not care to depart, further than the facts of the case made necessary." 211 Wisconsin, however, would be more forthright. "We are satisfied, therefore, that the general principles of the common law sustain [an employer's] liability, and that those cases which have attempted to establish an exception [to respondeat], do not rest upon solid ground."212 The court thereupon reversed the lower court, which had relied upon the rule, and remanded for a new trial.

When the case came up again the next year, the court reversed itself. ${ }^{213}$ Its reasons were clearly stated in the short opinion by Chief Justice Dixon, who had been a member of the majority the year before. The original judgment, he noted, had been "sustained by weighty and powerful reasons," and he had not changed his views regarding its correctness. ${ }^{214}$ Nevertheless, he noted, in the intervening year, Ohio had moved closer to the majority rule, and Wisconsin, therefore, "stands alone."215 $\mathrm{He}$ had switched his vote, therefore, "more from that deference and respect which is always due to the enlightened and well considered opinions of others, than from any actual change in my own views." "I think I am bound," he concluded, "to yield to this unbroken current of judicial opinion."218

Wisconsin exemplifies the intellectual pressures weighing upon judges who were disposed to dissent from the rule, pressures which grew stronger as the number of jurisdictions adopting the rule grew. Distinguishing the case before the court on its facts, and incidentally creating new exceptions, was therefore a much more comfortable approach than outright rejection.

Such a course, moreover, was often the only one open to a court, given the questions that the lawyers had presented to them for decision.

$210 \mathrm{Id}$. at 250.

211 Id. at 251.

212 Id. at 256-57. Justice Cole, concurring, would have preferred to come to the same conclusion through a narrow, technical analysis. His position was analogous to that of Hitchcock in Little Miami. See supra text accompanying notes 168-76.

21s Mosely v. Chamberlain, 18 Wis. 700 (1865). The case was decided in 1861, but appended to the 1865 official reports.

216 Id. at 705.

215 Id. at 706.

${ }^{216} \mathrm{Id}$. at 705 . 
In the cases of first impression considered in this Comment, no plaintiff's lawyer, save one, argued even in the alternative that a court should reject the rule. ${ }^{217}$ This was true not only in the late 1850's when the line of authorities had lengthened, but from the earliest cases. Rather than contesting the rule itself, lawyers invariably argued that their client's case constituted an exception. In Farwell itself, the plaintiff's lawyer did not question Priestley's holding or rationale. ${ }^{218}$

The lawyers, of course, were simply doing their jobs-attempting to gain a recovery for their clients with the least risk of a contrary decision. ${ }^{219}$ Their instinct to distinguish, rather than argue from principle, was a product of the practical, apprenticeship system of legal training that the vast majority of nineteenth-century lawyers had received. Lawyers who learned their trade by copying precedents and forms, rather than by studying underlying principles, were not likely to argue that a court should take any wider view of a case than was required to sustain the client's position. ${ }^{220}$

The courts, for their part, rarely reached out to decide questions that counsel had not presented to them. ${ }^{221}$ As Professor Greenleaf ad-

217 The exception was the plaintiff's lawyer in Little Miami, who argued strongly for an extension of respondeat in a 48 page brief. 20 Ohio at 423 . In Chamberlain v. Milwaukee \& Miss. R.R., 11 Wis. 238 (1860), the only other outright rejection of the rule, the court pointedly remarked that the court in its prior consideration of the case, 7 Wis. 425 (1859), had never reached the question of the rule's correctness because the point

seems not to have been contested there; probably for the reason that the plaintiff's counsel relied on the peculiar facts of the case, to make it an exception to the rule claimed, rather than on a denial of the rule itself.

Such being the case; the court was not called on to examine the question.

11 Wis. at 249-50.

${ }_{218} 45$ Mass. (4 Met.) at 51 (plaintiff's argument). See also the argument of the plaintiff's lawyer in Scudder v. Woodbridge, $1 \mathrm{Ga} .195,197$ (1846), another early case: "The general rule stated in McMullan [Murray] and Metcalf [Farwell] may be correct, and yet we must see that the exceptions, in justice and reason, must be numerous."

219 In this manner of proceeding, they differ little from contemporary counterparts. When faced with a series of contrary precedents, the safest and surest method is to distinguish. This practice exemplifies the "common feeling among lawyers . . . that it is not their business to be constructive but to operate the law as it is." A. WATSON, supra note 16 , at 121 .

${ }^{220}$ On the training of lawyers, see supra text accompanying notes 54-56.

221 Simpson, supra note 104, at 86; see also A. WATson, supra note 16 , at 121 ("[T] $\mathrm{T}$ he role of lawyers is central to legal development. The credit for legal progress must largely be given to them."). Modern commentators put strict limits upon a judge's ability to raise issues sua sponte. See, e.g., C. Wright, A. Miller \& E. Cooper, Federal Practice and Procedure, Civil $\S 2369$ (involuntary dismissal of action); Jurisdiction $\S 3522$ (want of jurisdiction); Jurisdiction $\S 4243$ (abstention, generally) (1982). While the rules were not as clear in the nineteenth century, the underlying rationale, which stems from the very nature of the adversarial system, was fully appreciated. On the proper role of a judge in an adversarial system, see L. Fuller, ThE Problem of Jurisprudence 706-07 (1949). 
vised students entering Harvard in 1838, "[f]ew judges, in our country, would deem it necessary to re-examine a cause, to discover what new path was left unexplored" by the lawyers. ${ }^{222}$

The judges who were called upon to decide whether the Fellow Servant rule should be applied in their jurisdictions, therefore, rarely were asked to consider whether the rule was correct, or the reasoning of the authorities sound. At most, counsel requested them to rule that the case of the particular plaintiff before them constituted an exception to the general rule. If a judge disapproved of the Fellow Servant rule, considering it incorrect in policy, or unsound in principle, then he and a majority of his brethren would find for the plaintiff. ${ }^{223}$ The immediate result would be the creation of a new "exception" to the Fellow Servant rule, ${ }^{224}$ and the cumulative result was the creation of an inco-

292 Greenleaf, supra note 109, at 221; see also Metcalf's Reports, 7 LAw REP. 1, 9 (1844) (reviewing Metcalfs Massachusetts Reports) ("It is often impracticable to ascertain the precise extent of the decision of the court, without knowing the grounds upon which the case was placed, and which the attention of the court was directed.").

${ }^{228}$ Exactly why these courts resisted the Fellow Servant rule is unclear. The reason may simply have been that these courts believed justice would be best served by leaving the liability for very serious injuries, negligently inflicted by one employee upon another, on the employer who was able to bear the cost, rather than upon the employee, who was not. Some jurists may also have believed that the employers bore a certain moral responsibility for their maimed employees. As Lord Cockburn wrote for the Scots Court of Sessions in Dixon v. Rankin, the case that rejected the English Fellow Servant rule:

I am clear for adhering to our own rule, and to our own legal and practical habits. The new rule seemed to be recommended to us ... on account of its own inherent justice. This last recommendation fails with me, because I think that the justice of the thing is exactly in the opposite direction .... I can conceive some reasons for exempting the employer from liability altogether; but not one for exempting him only when those who act for him injure one of themselves. It rather seems to me that these are the very persons who have the strongest claim upon him for reparation; because they incur damage on his account.

14 D. 420,426 (Scot.) (1852). This rationale was echoed in Keary, where the decision was grounded in the "social duty and public policy," that those who employ forces for their own benefit have a "duty to make reparation" if those forces cause harm. 3 Ohio St. at 207. Compare supra notes 74-75 and accompanying text.

Similarly, it is significant that the opinions rejecting the rule tended to detail the truly horrible injuries that railroad accidents inflicted. Thus, in Little Miami, Justice Caldwell described at length Stevens's injuries: "Stevens was very much injured by scalding; his recovery was doubtful for sometime, he was confined for months, and has been injured for life." 20 Ohio at 430 . Sympathy cannot be ruled out as a motivating force. In Farwell, by way of contrast, Shaw never in his lengthy opinion alluded to the serious injuries suffered by the plaintiff.

For whatever reasons individual jurists resisted the rule, however, such reasons were by no means determinative of the manner in which they expressed that dissent. The latter question has been the subject of this Comment.

224 A good example of a late creation of an exception is Tennessee. In Haynes v. East Tenn. \& Ga. R.R., 43 Tenn. 222 (1868) the body of the opinion is devoted to a long denunciation of the rule which concludes, "upon an examination of the authorities 
herent legal rule, inconsistent from one jurisdiction to another.

\section{CONCLUSION}

The creation of the Fellow Servant rule provides a case study of the nature of legal change in nineteenth-century America. If the process by which it was created was typical, one must conclude that judicial instrumentalism, which shaped legal rules to achieve economic and social goals, coexisted with and was tempered by intellectual norms within the legal community which exerted a powerful pull toward formalism and stability. The interplay of both these forces produced the Fellow Servant rule.

The rule was shaped by instrumentalist judges like Shaw of Massachusetts and Caldwell of Ohio, who responded to Fellow Servant cases with legal rules which, though opposite in result, drew their rationale from the economic and social realities of an industrializing society.

The spread of the rule from jurisdiction to jurisdiction, however, was largely due to judges who were motivated primarily by intellectual norms within the legal community. The history of the Fellow Servant rule demonstrates that the impetus to formalism was inherent in, and inseparable from, those norms, which placed a premium on short-range precedential consistency at the expense of long-range policy goals. As Simon Greenleaf explicated those norms to budding lawyers during the supposed heyday of instrumentalism, rules of law were to be "steadily adhered to," for "[ $t]$ he certainty and publicity of the rule are often of more importance than the nature of the rule itself." "The doctrines of the law," therefore, "as fixed and settled by a series of decisions, or as declared by a single deliberate judgment, are not to be departed from." 225

For a judge who responded to these norms, whether he adopted the rule or dissented from it, the bounds of his autonomy were clearly marked. Those judges who disagreed with the policies or premises of the rule were limited by the legal techniques of distinguishing and excepting, which provided an acceptable way of harmonizing authoritative precedents in the short run, but created legal chaos in the long run.

Other commentators have similarly concluded that "instrumental"

cited, we are unable to see upon what principle a rule that seems to us not founded in justice, nor common right should be upheld and maintained." 43 Tenn. at 227 . Yet the holding of the case is limited by the facts to the creation of a "superior servant" exception. A similar analysis in New Jersey, in Harrison v. Central R.R., 31 N.J.L. 293 (1865) led to the creation of a "master's duty of due care" exception.

s3s Greenleaf, supra note 109 , at 220. 
and "formalist" styles of judicial reasoning coexisted, rather than replaced one another, in the early nineteenth century. ${ }^{228}$ If this pattern is more general, therefore, future research should begin with the premise that instrumentalism and formalism were coexisting alternatives, whose interaction within one judicial system produced legal change by a process which has yet to be fully explained.

More specifically, the Fellow Servant cases indicate, at the least, that certain of Horwitz's conclusions should be qualified. His periodization of judicial styles, in which instrumentalist judges replace and then are replaced by formalist ones will not account for the pattern of coexistence described above. Moreover, the theories to which the judges resonded will not fit neatly into Horwitz's timeline. The cases suggest that an exaggerated respect for English precedent and a belief in common law myths of harmony and judicial "discovery" persisted far into the nineteenth century. Similarly, the underpinnings of judicial formalism, far from surfacing in the late nineteenth century, are inherent in a precedential legal system and significantly influenced the judges who adopted the Fellow Servant rule.

Finally, the development of the exceptions to the rule call into question the economic determinists' conclusions about the purposive nature of legal change. Horwitz depicted a process in which judges, armed with an instrumental conception of the power of law to aid the entrepreneurial classes, consciously and purposefully shaped private law to accomplish these ends. Yet the development of the Fellow Servant rule, with its contemporaneous creation of exceptions, was anything but purposive. Judges and lawyers created this misshapen rule out of the immediate needs of the case at hand with little concern for long-range consistency.

Once created, the rule remained on the books to enrich, as well as confuse, lawyers, not because of any positive judicial desire to keep the rule in place, but because of the powerful force of legal inertia. As one scholar wrote,

the maker of legal rules is in practice in somewhat the same position as the builder of an Atlantic liner: when he has built it, he must put up with it. In most cases, it cannot be seriously altered for years to come. This conflict between the

${ }^{228}$ See, e.g., Scheiber, supra note 50 , at 8 , whose study of the development of American riparian law yielded the conclusion that "the picture was thus a mixed one in the 1820-50 period-with 'instrumentalist' judges often invoking formalistic doctrine, and the doctrinaire critics adducing instrumental arguments." On the contemporary coexistence of these alternative styles of judicial reasoning, see Ursin, supra note 9. 
rational and the arbitrary is very old and seems inseparable from law. ${ }^{227}$ 